Notre Dame Law School

NDLScholarship

Journal Articles

Publications

2010

\title{
Anna Nicole Smith Goes Shopping: The New Forum-Shopping Problem in Bankruptcy
}

G. Marcus Cole

Notre DameLaw School, gcole2@nd.edu

Todd J.Zywicki

Follow this and additional works at: https://scholarship.law.nd.edu/law_faculty_scholarship

Part of the Bankruptcy Law Commons

\section{Recommended Citation}

G. Marcus Cole \& Todd J. Zywicki, Anna Nicole Smith Goes Shopping: The New Forum-Shopping Problem in Bankruptcy, 2010 UTAH L. REV. 511, 546 (2010).

Available at: https://scholarship.law.nd.edu/law_faculty_scholarship/1385

This Article is brought to you for free and open access by the Publications at NDLScholarship. It has been accepted for inclusion in Journal Articles by an authorized administrator of NDLScholarship. For more information, please contact lawdr@nd.edu. 


\title{
ANNA NiCOLE SMITH GoES SHOPPING: THE NEW ForUM-SHOPPING PROBLEM IN BANKRUPTCY
}

\author{
G. Marcus Cole* \& Todd J. Zywicki**
}

\section{INTRODUCTION}

In the United States, relations between debtors and their creditors are governed by two distinct legal regimes. For the overwhelming majority of credit relationships, state law of contract, property, tort, and consumer protection set up the framework within which the debtor-creditor relationship is established, functions, and in the end, is dissolved. In a smaller but significant number of these relationships, a different forum orchestrates the end of these relationships, namely, federal bankruptcy court. These two distinct forums for debtor-creditor relations coexist side by side, with some disputes moving over time from one forum to the other. As with any system where dual regimes for dispute resolution exist, parties seeking resolution of debtor-creditor disputes can and will, under the right conditions, engage in "forum shopping."

In his seminal work, The Logic and Limits of Bankruptcy Law, ${ }^{1}$ Thomas Jackson describes the central dilemma with which bankruptcy law has struggled throughout its history as "the forum-shopping problem."2 How can a bankruptcy regime efficiently provide a separate bankruptcy forum to advance bankruptcy policies while at the same time prevent parties from opportunistically using bankruptcy simply to gain a better substantive result than they would receive outside in state court under state law? The "nightmare" forum-shopping scenario is one in which a dispute between two parties receives dramatically different treatment depending upon which forum was used to adjudicate the dispute.

The solution to the forum-shopping problem, recognized long before Jackson formally framed the question, has been to craft a bankruptcy regime that treats creditors and debtors substantively the same inside the bankruptcy forum as they

* 2010 G. Marcus Cole, The Wm. Benjamin Scott \& Luna M. Scott Professor of Law, Stanford Law School, and Visiting Professor of Law \& Economics, Universiteit van Amsterdam.

** (C) 2010 Todd J. Zywicki, George Mason University Foundation Professor of Law, George Mason University; Searle Fellow, George Mason University School of Law (Fall 2008). We would like to thank Adam Aft and Jeffrey Frank for research assistance and the Koch Project in Corporate Federalism at George Mason University School of Law for financial support. This Article was partially written while Professor Zywicki was a Searle Fellow at George Mason University School of Law and he thanks the Searle Foundation for its generous support.

${ }_{1}^{1}$ ThOMAS H. JACKSON, THE LOGIC AND Limits OF BANKRUPTCY LAW (1986).

2 JACKSON, supra note 1, at 21-22; see also DOUglas G. BAIRD \& THOMAS H. Jackson, Cases, Problems, AND Materials on BankruptCy 50-52 (2d ed. 1990) (analogizing bankruptcy courts and state courts to two different courts in two different cities, but noting that parties can bring litigation in either). 
would be treated outside of it and to merely change the procedures by which substantive rights are vindicated. In sum, bankruptcy has long served as a place with special procedures, but, for the most part, with no special substantive law.

This principle of symmetry between bankruptcy and non-bankruptcy treatment of claims and defenses is now known as the Butner principle, because of the Supreme Court's articulation of it in that case. ${ }^{3}$ The principle long predates that case, however, since it was the crucial lynchpin of the great compromise of 1898 that gave the United States its first lasting bankruptcy law. ${ }^{4}$ The principle is also embodied in bankruptcy law's most important and famous rule, the "absolute priority" rule, which states that priorities between creditors inside of bankruptcy must reflect the ordering of those priorities outside of bankruptcy. ${ }^{5}$ The Butner principle has been rearticulated by courts on numerous occasions, most importantly, by the Supreme Court in Granfinanciera v. Nordberg. ${ }^{6}$

According to Butner, courts sitting in bankruptcy are to employ bankruptcy procedure to administer rights and obligations established under non-bankruptcy law. ${ }^{7}$ The Butner Court explicitly identified the forum-shopping problem that would arise from permitting a party to receive "a windfall merely by reason of the happenstance of bankruptcy."8

This separation of substantive and procedural law, which long served as the guiding principle of American bankruptcy law, is threatened by a new type of forum shopping. In order to achieve outcomes unavailable outside of bankruptcy forums, some litigants have identified a nuance of bankruptcy jurisdiction that, if interpreted in a particular way, has the ability to overturn the substantive law of their cases.

The new forum-shopping problem in bankruptcy is rooted in the interpretation of a statutory provision. Whatever the policy or principles underlying bankruptcy, it remains an equity regime created by statute, namely, the Bankruptcy Code of 1978 (the Bankruptcy Code). ${ }^{9}$ As a fundamental component of that regime, bankruptcy jurisdiction is likewise a creature of statute. Section $157(\mathrm{~b})(1)$ of title 28 of the United States Code authorizes bankruptcy courts to enter final judgments in "all core proceedings arising under title 11, or arising in a case under title 11."10

${ }^{3}$ Butner v. United States, 440 U.S. 48, 54-56 (1979).

${ }^{4}$ For a complete explication of the history of the Bankruptcy Act of 1898, see DAVID A. SKEEl, JR., DEBT'S DOMINION: A HISTORY OF BANKRUPTCY LAW IN AMERICA 1-70 (2001).

${ }^{5}$ The absolute priority rule is embodied in 11 U.S.C. $\$ 1129$ (b)(2)(B)(ii) (2006).

${ }^{6} 492$ U.S. 33, 36, 64 (1989) (illustrating the symmetry between bankruptcy and nonbankruptcy treatment of claims by holding that a party has the right to a jury trial when sued in bankruptcy court under legal rather than equitable causes of action).

${ }^{7}$ Butner, 440 U.S. at 54-57; Travelers Cas. \& Sur. Co. of Am. v. Pac. Gas \& Elec. Co., 549 U.S. 443, 450-51 (2007).

${ }^{8}$ Butner, 440 U.S. at 55 (quoting Lewis v. Mfrs. Nat'l Bank, 364 U.S. 603, 609 (1961)).

${ }^{9}$ See Celotex Corp. v. Edwards, 514 U.S. 300, 328 (1995).

${ }^{10} 28$ U.S.C. $\S 157(b)(1)(2006)$. 
If an Article I bankruptcy court has the power to enter final orders and judgments in "all core proceedings," as some litigants have suggested, then these bankruptcy courts become rivals of state and federal non-bankruptcy courts, with the potential to reverse outcomes achieved under, or determined by, non-bankruptcy law. On the other hand, if $\S 157(\mathrm{~b})(1)$ is interpreted in a manner consistent with the Butner principle, as well as the Supreme Court's recognition of constitutional limits on the scope of bankruptcy jurisdiction in Northern Pipeline Construction Co. v. Marathon Pipe Line Co., ${ }^{11}$ then this new conduit for forum shopping is foreclosed.

More precisely, in order for there to be final order jurisdiction under $\S 157(b)(1)$, the matter must be a "core" matter that also either "arises in" or "arises under" a case under title $11 .^{12}$ To render a final judgment, it is never sufficient to be simply a core matter. It is the "arises in" and "arises under" requirements that vindicate relevant constitutional principles by limiting the reach of the bankruptcy court's final order jurisdiction.

This Article proceeds in four parts. Part II describes the "core" and "noncore" distinction in bankruptcy jurisdiction, and the significance of that distinction for final orders in bankruptcy. This section also describes the new forum-shopping problem, and how bankruptcy courts and litigants might interpret $\S 157$ to achieve outcomes dramatically different from what might occur outside of bankruptcy. The best example of this new forum-shopping problem is provided by Marshall $\nu$. Marshall,$^{13}$ the famous "Anna Nicole Smith" case, in which a bankruptcy court in California set a Texas Probate Court judgment on its head. ${ }^{14}$ The "nightmare" forum-shopping case has been realized. ${ }^{15}$

Part II explores the key question confronting the Marshall Court, which is: "When can an Article I bankruptcy court enter a final order?" If $\S 157$ is interpreted expansively, so as to characterize a matter of private rights arising under state law to be subject to an Article I bankruptcy court's final order

${ }^{11} 458$ U.S. 50, 87 (1982).

${ }^{12} 28$ U.S.C. $\$ 157(\mathrm{~b})(1)$.

${ }^{13}$ Marshall v. Marshall (In re Marshall), 253 B.R. 550 (Bankr. C.D. Cal. 2000).

${ }^{14} \mathrm{Id}$.

${ }^{15}$ We hasten to clarify that not all forum shopping is inefficient or inconsistent with the rule of law. Contractual choice of law or choice of forum clauses, for example, are efficiency-enhancing and fully consistent with the rule of law, even if this produces results different from what would otherwise result. Put loosely, the fundamental difference is whether the forum shopping that occurs is created by ex ante agreement by the parties (either implicitly or explicitly) or ex post unilateral choice by one party. The former is likely to promote efficiency and the latter is likely to reduce it. For a detailed examination of the circumstances under which forum shopping is likely to produce positive versus negative results, see Todd J. Zywicki, Is Forum Shopping Corrupting America's Bankruptcy Courts?, 94 GEO. L.J. 1141, 1180-85 (2006) [hereinafter Zywicki, Corrupting]. For an argument that the Supreme Court's decision in Erie R.R. v Tompkins, 304 U.S. 64 (1938) failed to appreciate this important distinction, and thus eliminated both beneficial and negative forum shopping, see Todd J. Zywicki, The Rise and Fall of Efficiency in the Common Law: A Supply-Side Analysis, 97 Nw. U. L. REV. 1551, 1613-20 (2003) [hereinafter Zywicki, Rise and Fall]. 
jurisdiction, then a party may, as in Marshall v. Marshall, seek a different result by filing bankruptcy - the very forum-shopping nightmare that basic bankruptcy principles seek to avoid. Part II shows that the "core versus non-core" distinction is critical in Marshall because it determines the proper application of preclusion principles. If the probate matter was not a core proceeding, then the bankruptcy court's decision was thus not a final judgment, and the Texas Probate Court's subsequent judgment would have been the first final judgment in the matter and should have been preclusive on the district court, effectively defeating forum shopping. Because bankruptcy law has no insolvency requirement and few other legal limitations on the assertion of bankruptcy jurisdiction, and judges generally hold often-asserted broad equitable authority to administer claims, ${ }^{16}$ Marshall fundamentally threatens the integrity of the rule of law and fair administration of justice. Indeed, for these reasons, the forum-shopping concern between federal bankruptcy courts and other courts, as exemplified in Marshall, is fundamentally identical to the forum-shopping concern between state and federal courts addressed by the Supreme Court in the canonical case of Erie Railroad v. Tompkins itself. ${ }^{17}$

Part III explains the constitutional history and structure of modern bankruptcy jurisdiction. This Part then employs that history and structure to explain why interpretations of $\S 157$, which might promote forum shopping, while linguistically plausible, are nevertheless inconsistent with Supreme Court proclamations about the constitutional constraints upon bankruptcy jurisdiction.

Part IV explores the policy justifications for a limited bankruptcy jurisdiction, rooted both in the Butner principle as well as in Congress's response to the Supreme Court's ruling in Northern Pipeline Construction Co. v. Marathon Pipe Line Co., in which the Court held the jurisdictional scheme provided by the Bankruptcy Code to be unconstitutional. ${ }^{18}$ Given the history and application of standard canons of statutory construction, Article I bankruptcy courts are not granted sweeping authority to enter final orders in all "core proceedings." Instead, a bankruptcy court's final order jurisdiction is limited to the more narrow set of cases "arising under title 11" and "arising in a case under title 11." Finally, we close by describing the Ninth Circuit's ruling in the case of Marshall v. Stern, which held that Anna Nicole Smith's counterclaim was not a core proceeding and that, as a result, the Texas Probate Court's denial of any right to further payment from Marshall's estate was controlling. ${ }^{19}$ In our view, while that opinion reaches the right result in this particular case, we fear that its reasoning is insufficiently attentive to the dangers of forum shopping in future cases. We prefer the views expressed in the concurring opinion in the case, which we think reflects greater attention to these dangers.

${ }^{16}$ See 11 U.S.C. $\S \S 105,109$ (2006).

${ }^{17}$ Erie R.R. v. Tompkins, 304 U.S. 64 (1938).

${ }^{18} 458$ U.S. 50,87 (1982).

${ }^{19}$ Marshall v. Stern (In re Marshall), 600 F.3d 1037, 1060-61 (9th Cir. 2010). 


\section{BANKRUPTCY JURISDICTION AND THE NEW FORUM-SHOPPING PROBLEM}

\section{A. The Structure of Bankruptcy Jurisdiction}

The subject matter jurisdiction of bankruptcy courts has long been a matter of controversy, haunted principally by two types of concerns. First, as a system for resolving the relationships between a debtor and his creditors, bankruptcy necessarily must contemplate exercising jurisdiction over third parties and their interests, to the extent that those interests intertwine with the property and interests of the debtor. ${ }^{20}$ Second, to the extent that bankruptcy operates as a parallel universe to state legal systems for the resolution of creditors' claims on debtors, it unavoidably "competes" with these state legal systems as a forum for the resolution of disputes.

The bankruptcy jurisdiction system could have been constructed in any number of ways. First, it would have been possible to have no federal bankruptcy system at all, and to simply rely on state law debt-collection systems to determine who gets what from a bankrupt debtor. State law is typically a "race of diligence"- those creditors who are most diligent and aggressive in enforcing their rights are protected first and those who are more passive run the risk of nonpayment. Alternatively, it is conceivable to have a debt-collection system that is entirely federal and for which the collection of even the most mundane credit card debt, even from a solvent debtor, requires elaborate collective processes. In this system, the federal bankruptcy court would administer a collective proceeding that looks out for the interests of all creditors, not just the diligent ones-even where the debtor is likely solvent, making such protections unnecessary.

In contrast to both of these extremes, the architects of the American bankruptcy laws constructed a hybrid system that combines state and federal law systems. ${ }^{21}$ The system is grounded as an initial matter on the foundation of state laws that establish the substantive entitlements for debtors and creditors and set the substantive background rules of tort, contracts, property, and trusts and estates. ${ }^{22}$ Because of this longstanding premise of grounding substantive entitlements in state law, combined with the cost and delay of the collective proceeding associated with the federal bankruptcy laws-and more importantly, precisely to address concerns about improper forum shopping - the operative principle for bankruptcy law is that bankruptcy jurisdiction must be earned, not merely presumed. Cases are moved from state court into bankruptcy court only if some bankruptcy policy is furthered. For instance, bankruptcy jurisdiction is inappropriate for trusts that have

${ }^{20}$ See, e.g., 11 U.S.C. $§ 362$ (a) (enjoining all entities from taking almost any action outside of the bankruptcy process which would affect a debtor's property).

${ }^{21}$ See, e.g., 11 U.S.C. $\S 522$ (allowing for the adoption of state law on exemption of property); id. $\S 541$ (designating all legal and equitable interests as property of the estate); id. $\S 544$ (creating rights in the trustee based on the powers allowed to certain lien creditors under relevant state law).

${ }^{22}$ See, e.g., id. $\S \S 522,541,544$. 
no operating assets or otherwise do not function as an operating business, ${ }^{23}$ or for entities that have alternative mechanisms for resolving financial distress, such as banks and insurance companies. ${ }^{24}$ In the case of nonoperating trusts, insolvency raises no coherent bankruptcy issues-such as collective action problems or preservation of going-concern value - and thus such cases can be processed under standard state debtor-creditor law. ${ }^{25}$ The insolvency of banks or insurance companies does raise bankruptcy-type problems, but those bodies of law provide specific rules for the resolution of insolvency, thus bankruptcy is again unnecessary. ${ }^{26}$ Most fundamentally, there is nothing in the history or policy of bankruptcy law that suggests that it is an appropriate use of bankruptcy law to simply get a second bite at the apple - to rewrite or trump substantive state lawwhen it is not necessary to further any coherent bankruptcy policy.

Adopting either a purely state or purely federal system would eliminate the potential confusion and forum-shopping concerns of establishing whether borderline cases should proceed in bankruptcy court. Despite these dangers, the two systems generally coexist peacefully, at least where judges are vigilant about protecting the boundary lines between them. But the danger in the system is evident-the temptation to trigger bankruptcy jurisdiction to achieve some improper goal rather than to further bankruptcy policies. As a conceptual matter, the dividing line between the bankruptcy and non-bankruptcy worlds is insolvency; but requiring insolvency as a bright-line rule proved elusive as an administrative matter, so under the modern Bankruptcy Code, it is not a formal requirement. ${ }^{27}$

This compromise also has deep historical roots. It was the source of strong disagreements between proponents of federal bankruptcy legislation throughout the nineteenth century, and is one reason why no lasting bankruptcy law was passed in

${ }^{23}$ Compare 11 U.S.C. $\S 101(9)$, (41) (defining which business entities qualify as a person and excluding non-business trusts), with 11 U.S.C. $\$ 109$ (limiting bankruptcy to persons, municipalities, and certain non-trust organizations); see also In re Treasure Island Land Trust, 2 B.R. 332, 333-34 (Bankr. M.D. Fla. 1980).

${ }^{24}$ See, e.g., 11 U.S.C. $\S 109$ (prohibiting bankruptcy for any bank insured by the FDIC); 12 U.S.C. $\S 191$ (2006) (empowering the Comptroller of the Currency to place such banks in receivership with the FDIC); see also FDIC, RESOLUTIONS HANDBOOK 67 (2003), available at http://www.fdic.gov/bank/historical/reshandbook/ch7recvr.pdf (comparing FDIC receivership over banks with bankruptcy).

${ }^{25}$ This is because nonoperating trusts operate in a manner much more akin to properties than to business entities.

${ }^{26}$ See, e.g., 12 U.S.C. $\S \S 191,203,1821$ (c)(5) (2006) (allowing federal regulators to place national banks in receivership or conservatorship for a range of bankruptcy-type problems).

${ }^{27}$ At least one commentator has argued that insolvency should be a jurisdictional requirement for bankruptcy and has suggested that the absence of an insolvency requirement raises bankruptcy forum-shopping concerns. See Thomas E. Plank, Why Bankruptcy Judges Need Not and Should Not Be Article III Judges, 72 AM. BANKR. L.J. 567, 620-29 (1998). 
the United States until $1898 .^{28}$ Indeed, the tension between state and federal approaches to debtor-creditor relations served as the point of compromise that allowed passage of the Bankruptcy Act of $1898 .{ }^{29}$ This first, lasting bankruptcy law was only possible once proponents of a federal system agreed to reduce the system to a procedural mechanism which would incorporate and apply state substantive law, particularly with regard to state exemption regimes. ${ }^{30}$ Whether it is the result of reasoning from first principles, or from continued political compromise, this initial structure continues today.

Despite the equilibrium that was achieved through the compromise of 1898 , forum shopping in bankruptcy became problematic with amendments to the Act throughout the twentieth century. ${ }^{31}$ Strategic forum shopping within the Act became a familiar practice, with corporate debtors often trying to manipulate jurisdictional requirements to become eligible to use the more flexible and management-friendly restructuring provisions of chapter XI over the more rigid formalities of chapter $X$ in order to avoid the oversight of the Securities and Exchange Commission and the associated delays. ${ }^{32}$

These forum-shopping difficulties were part of the problem that eventually led Congress to seek a complete overhaul of the Bankruptcy Act. With the passage of the Bankruptcy Code, Congress sought to create a forum for the resolution of the collective action problem presented by insolvency, while preserving respect for state debtor-creditor law. ${ }^{33}$ Nowhere is this intention more evident in the Bankruptcy Code than with its preservation of the "substance versus procedure" distinction originally adopted in the 1898 Act. $^{34}$ Congress could not foresee, however, that the preservation of the Act's solution to the forum-shopping problem would be incapable of stemming the problem of forum shopping entirely. The limited reach of the "substance versus procedure" solution became particularly clear after the Supreme Court's decision in Northern Pipeline Construction Co. $v$. Marathon Pipe Line Co. made an overhaul of the Bankruptcy Code's jurisdictional scheme necessary. ${ }^{35}$

${ }^{28}$ See G. Marcus Cole, Limiting Liability Through Bankruptcy, 70 U. CIN. L. REV. $1245,1267-68(2002)$.

${ }^{29}$ See SKEEL, supra note 4, at 23-47.

${ }^{30}$ See G. Marcus Cole, The Federalist Cost of Bankruptcy Exemption Reform, 74 AM. BANKR. L.J. 227, 245-46 (2000).

${ }^{31}$ See SKEEL, supra note 4, at 131-51.

${ }^{32}$ Id. at $160-66$.

${ }^{33}$ See, e.g., 11 U.S.C. $\S \S 522,541$ (2006).

${ }^{34}$ Bankruptcy Act, ch. 541, 30 Stat. 544 (1898).

${ }^{35} 458$ U.S. 50, 87 (1982) (holding the Bankruptcy Code unconstitutional because it extended the judicial power of the United States to judges without life tenure during good behavior). 


\section{B. "Core"vs. "Non-Core" Jurisdiction in Bankruptcy}

Enacted as part of the 1984 Bankruptcy Amendments and in response to the Supreme Court's decision in Marathon Pipe Line, 28 U.S.C. $\S 157$ created a new jurisdictional structure, one that distinguished between "core" bankruptcy jurisdiction and "non-core" bankruptcy jurisdiction. ${ }^{36}$ The extent of a bankruptcy court's jurisdiction-and in turn, its power-is determined by whether the subject matter of the proceeding at issue is a core matter or a non-core matter. ${ }^{37}$

\section{28 U.S.C. $\S 157$}

The statute does not define "core" proceedings, but $\S 157(\mathrm{~b})(2)$ does provide a list of examples. ${ }^{38}$ These examples, however, are nonexclusive and include amorphous language, such as, "other proceedings affecting the liquidation of the assets of the estate or the adjustment of the debtor-creditor or the equity security holder relationship." 39

As the Second Circuit has observed, "[t]he language of that sub-section $[\$ 157(\mathrm{~b})(2)]$ could be construed to include almost any matter related to bankruptcy, but the structure of the statute as a whole does not permit such a construction. Matters that merely concern the administration of the bankrupt estate tangentially are related, non-core proceedings."40 Courts have occasionally struggled to define the contours of $\S 157(\mathrm{~b})(2)$ when a matter does not fall within the precise terms of one of the examples.

One court has defined a matter as core "if it invokes a substantive right provided by title 11 or if it ..., by its nature, could arise only in the context of a bankruptcy case." ${ }^{41}$ Core proceedings, therefore, are those actions arising from "public rights" created by Congress's enactment of the Bankruptcy Code. ${ }^{42}$ Because those rights are defined solely by Congress in creating the statute, Congress also may define the mechanisms for the adjudication of those rights, such as allocating disputes over their resolution to bankruptcy courts.

A non-core matter, by contrast, is predicated on the vindication of rights that arise outside bankruptcy, under either state law or federal non-bankruptcy law. ${ }^{43}$ Thus, a matter that could have been brought in a state court is necessarily a noncore proceeding, for which bankruptcy judges exercise their more limited powers.

\footnotetext{
${ }^{36} 28$ U.S.C. $\S 157$ (2006).

${ }^{37} \mathrm{Id} . \S 157(\mathrm{~b})(2)$.

${ }^{38} \mathrm{Id}$.

${ }^{39} I d$. $\S 157(\mathrm{~b})(2)(\mathrm{O})$.

${ }^{40}$ Ben Cooper, Inc. v. Ins. Co. of Pa. (In re Ben Cooper, Inc.), 896 F.2d 1394, 1398
} (2d Cir. 1990).

${ }^{41}$ Wood v. Wood (In re Wood), 825 F.2d 90, 97 (5th Cir. 1987).

42 See N. Pipeline Constr. Co. v. Marathon Pipe Line Co., 458 U.S. 50, 71 (1982).

${ }^{43}$ See Broyles v. U.S. Gypsum Co., 266 B.R. 778, 783 (E.D. Tex. 2001). 
Bankruptcy judges may hear both core and non-core proceedings. ${ }^{44}$ Non-core proceedings may also fall within the jurisdiction of a federal court sitting in bankruptcy. ${ }^{45}$ A non-core matter may be heard by an Article I bankruptcy judge as long as "the outcome of that proceeding could conceivably have any effect on the estate being administered in bankruptcy. ${ }^{, 46}$ This means that even matters for which the rule of decision is state law or federal non-bankruptcy federal law can be heard by an Article I bankruptcy judge. ${ }^{47}$

The critical importance of the determination that a matter is a core proceeding is thus not one of jurisdiction but rather power: Article I bankruptcy judges may enter final judgments and orders only in a core proceeding. ${ }^{48}$ If a matter is noncore, by contrast, a bankruptcy judge may only submit "proposed findings of fact and conclusions of law to the district court, subject to de novo review."

\section{Northern Pipeline v. Marathon Pipe Line}

The distinction between core and non-core matters is crucial, albeit elusive. The Supreme Court addressed the question in Northern Pipeline Construction Co. v. Marathon Pipe Line Co ${ }^{50}$ In that case, commonly referred to as Marathon, Northern Pipeline was reorganizing under chapter 11 of the then-new Bankruptcy Code. ${ }^{51}$ Within the bankruptcy case, the debtor (Northern Pipeline) filed a breach of contract action against Marathon Pipe Line. ${ }^{52}$ There was no disagreement about whether the bankruptcy court had jurisdiction over the lawsuit. ${ }^{53}$ Defendant Marathon Pipe Line, however, challenged the bankruptcy court's authority to exercise Article III judicial power over the case. ${ }^{54}$ Marathon argued that an exercise of Article III judicial power by a court established by Congress under Article I violated the Constitution's separation of powers doctrine. ${ }^{55}$

In a holding joined by six justices, the Supreme Court agreed with Marathon Pipe Line that the Bankruptcy Code conferred upon bankruptcy judges the power to hear a state-based breach of contract claim-like that asserted by Northern Pipeline-but that, as a non-Article III court, a bankruptcy court could not

${ }^{44}$ Sheridan v. Michels (In re Sheridan), 362 F.3d 96, 103 n.5 (1st Cir. 2004) (citing. 28 U.S.C. $\S 157(\mathrm{c})(1)(2006))$.

${ }^{45} 28$ U.S.C. $\S 157(\mathrm{c})(1)$.

${ }^{46}$ In re Wood, 825 F.2d at 93 (quoting Pacor, Inc. v. Higgins, 743 F.2d 984, 994 (3d

Cir. 1984)).

${ }^{47} \mathrm{Id}$. at 95 .

${ }^{48} 28$ U.S.C. $\S 157(\mathrm{~b})$.

${ }^{49}$ In re Wood, 825 F.2d at 95.

${ }^{50} 458$ U.S. 50 (1982).

${ }^{51}$ Id. at 56 .

${ }^{52}$ Id.

${ }^{53}$ Id.

${ }^{54} \mathrm{Id}$. at $56-57$.

${ }^{55} I d$. 
constitutionally be vested with jurisdiction to decide such state law claims. ${ }^{56}$ As Justice Brennan wrote in his opinion, the state law contract claim:

[M]ay be adjudicated in federal court on the basis of its relationship to the petition for reorganization. But this relationship does not transform the state created right into a matter between the Government and the petitioner for reorganization. Even in the absence of the federal scheme, the plaintiff would be able to proceed against the defendant on the statelaw contractual claims. ${ }^{57}$

The test, then, for whether a matter is a non-core matter, subject to a bankruptcy judge's more limited power to merely submit proposed findings of fact and conclusions of law, is whether the case could have been brought in the absence of a bankruptcy proceeding. As the Supreme Court reasoned in Marathon, if Congress can create particular rights, then Congress can also establish courtseven non-Article III courts-to adjudicate those rights. ${ }^{58}$ As one bankruptcy court. has commented, "[C]ore proceedings represent those disputes so intertwined with the bankruptcy process that Congress has the power under Article I of the Constitution to direct a non-tenured judicial officer to render a final determination of its merits. ${ }^{, 59}$ Non-core matters, by contrast, are those that are related in some way to a bankruptcy case but are not within the "exclusive province" of the bankruptcy courts. ${ }^{60}$

The new forum-shopping problem arises when core jurisdiction is viewed expansively, so as to effectively place bankruptcy judges on an equal footing with state courts and Article III federal courts when resolving disputes wholly independent of the existence of a bankruptcy proceeding-disputes rooted in private, non-bankruptcy rights and obligations. Since an insolvency requirement has long proven an infeasible and elusive specter throughout bankruptcy history, nearly anyone, even a perfectly solvent individual or corporate entity, may file for bankruptcy protection. ${ }^{61}$ Thus, if a litigant has concerns about how a state court or federal district court might resolve her dispute, the statute arguably authorizes her to file a petition in bankruptcy. On the other hand, even if Congress places no express limits on the statutory language (although properly read, it does place some express limits), Marathon and foundational principles of bankruptcy law impose implicit limits.

${ }^{56} \mathrm{Id}$. at $71-72$.

${ }^{57}$ Id. at 72 n.26 (citations omitted).

${ }^{58} \mathrm{Id}$. at 80.

${ }^{59}$ Adams v. Prudential Sec., Inc. (In re Found. for New Era Philanthropy), 201 B.R. 382, 387 (Bankr. E.D. Pa. 1996).

${ }^{60} 1$ William L. NORTON, Norton BankRuptcy Law aND Practice $\$ 4: 65$ (3d ed. 2008).

${ }^{61}$ See Cole, supra note 28 , at 1253. 


\section{Forum Shopping Through Bankruptcy Jurisdiction}

\section{The New Forum-Shopping Problem}

The old forum-shopping problem may have been largely abated by the structure of the Bankruptcy Code and the Supreme Court's interpretation of it in Butner. The new forum-shopping problem is largely a creature of statute, or more accurately, the vagaries of the statute. A confusing deployment of terms within title 28 have permitted bankruptcy courts to assume jurisdiction and power that flaunts the bright constitutional line drawn by the Court in Marathon, as well as the longstanding respect for state law in a federalist system.

In the hands of an activist bankruptcy judge, this development threatens to undo the careful balance between federal and state law crafted over the past 110 years of American bankruptcy law and to spawn a race to the courthouse that could upset long-established principles of tort, property, and contract law that underlie our legal system. There is no evidence that Congress intended the stability of the American legal system and the law of testamentary succession to turn on the whim of Article I bankruptcy judges and a naked hope that judges would use this proffered power responsibly. Instead, although bankruptcy judges' authority is broad, it is not unlimited. There are clear constitutional and statutory limits to rein in bankruptcy judges who exceed their authority ${ }^{62}$ and it is essential that those restraints be enforced. Otherwise, every probate court case could be subject to a race to the courthouse as disgruntled claimants seek a rehearing of their state law rights before a bankruptcy judge. Moreover, strategic forum shopping might not be limited only to debtors, but might also include opportunities for creditors to trigger involuntary bankruptcy proceedings if they believe that the bankruptcy court will provide a more favorable forum.

The dangers of the new forum-shopping problem are no more dramatically demonstrated than in the recent tabloid-fodder case of Marshall v. Marshall. ${ }^{63}$

\section{Forum-Shopping in Marshall v. Marshall}

If pulp-fiction novelists or Hollywood screenwriters attempted to craft an example of pernicious forum shopping from scratch, they would be hard-pressed to envision a more troubling story than Marshall $v$. Marshall. The case is famous, not because of its legal complexities or nuances, but rather for its celebrity litigant. It revolved around the financial affairs of the widow of the late J. Howard Marshall II, namely, Vickie Lynn Marshall, popularly known as Anna Nicole Smith. ${ }^{64}$

The case, more accurately characterized as "cases," began shortly before the death of J. Howard Marshall II. Marshall had been a successful law professor,

6228 U.S.C. $\S 157$ (2006).

${ }^{63}$ In re Marshall, 392 F.3d 1118 (9th Cir. 2005), rev'd and remanded sub nom. Marshall v. Marshall, 547 U.S. 293 (2006).

${ }^{64}$ Marshall v. Marshall, 547 U.S. 293, 293 (2006). 
lawyer, public servant, and oil company executive over a long and distinguished career. ${ }^{65}$ Marshall met Smith shortly after the second of his two thirty-year marriages ended with the death of his second wife. ${ }^{66}$ Smith, an exotic dancer, actress, and 1993 Playboy Magazine Playmate of the Year, met Marshall in 1991 in the Houston club where she performed. ${ }^{67}$ The two married in June 1994, and the sixty-three year difference in their ages gave rise to public speculation that Smith had married Marshall for his money ${ }^{68}$ The marriage was short-lived. Just thirteen months after marrying Smith, Marshall died, leaving an estate valued by some estimates at over a billion dollars. ${ }^{69}$

The litigation over Marshall's estate actually began before his passing and has lasted almost ten times longer than the star-crossed marriage that spawned it. Four months before his death, Smith filed an action in Texas Probate Court seeking to invalidate Marshall's estate plan. ${ }^{70}$ Marshall, a former professor at Yale Law School, had crafted in 1982 an estate plan consisting of a "pour-over" will and a living trust which provided for the disposition of Marshall's property. ${ }^{71}$ Marshall gave Smith millions of dollars worth of gifts while he was living, but he never put any property in the trust for Smith's use and benefit. ${ }^{72}$ Smith brought the Texas probate action in an attempt to invalidate the trust. ${ }^{73}$

Three days after Marshall's death, Smith contested the administration of the will and the estate plan. ${ }^{74}$ She further claimed that Marshall had orally promised to give her much more of his estate, and had instructed his attorneys to construct a "catch-all" trust for her benefit, but that this plan was thwarted by Marshall's son, E. Pierce Marshall, leading Smith to subsequently file a charge of tortious interference with an inter vivos gift. ${ }^{75}$

The Texas probate case was pending when Smith's activities in another forum interrupted the proceedings. Maria Antonia Cerrato, a former housekeeper and nanny to Smith's child from a prior marriage, filed suit against Smith for sexual

${ }^{65}$ See Brief of Respondent at 3, Marshall, 547 U.S. 293 (No. 04-1544); Ronald A. Cass, Marshall v. Marshall and the Probate Exception to Federal Court Jurisdiction, FEDERALIST SOC'Y FOR L. \& PUB. POL'Y STUD., 2 (Jan. 16, 2007), http://www.fedsoc.org/doclib/20070322_MarshallvMarshall.pdf.

${ }^{66}$ Marshall v. Marshall (In re Marshall), 275 B.R. 5, 20-21 (C.D. Cal. 2002).

${ }^{67} \mathrm{Id}$.

${ }^{68} I d$. at 23.

${ }^{69}$ Marshall v. Marshall, 547 U.S. at 300; Marshall v. Marshall (In re Marshall), 273 B.R. 822, 824 (Bankr. C.D. Cal. 2002).

${ }^{70}$ Marshall v. Marshall (In re Marshall), 392 F.3d 1118, 1123-25 (9th Cir. 2004).

${ }^{71}$ Id.; In re Marshall, 275 B.R. at 11 n.5.

${ }^{72}$ In re Marshall, 392 F.3d at 1122.

${ }^{73}$ Cf. In re Estate of Marshall, No. 276815 (Harris Cnty. Prob. Ct. Aug. 7, 1995), available at http://www.cclerk.hctx.net/applications/websearch/Probate.aspx?DocketNo= 276815 (showing the date Smith filed to contest administration of the estate).

${ }^{74}$ Id.

${ }^{75}$ Marshall v. Marshall, 547 U.S. 293, 300-01 (2006). 
harassment and received a default judgment for $\$ 884,607.98 .{ }^{76}$ In January 1996 , in response to the judgment, Smith filed for bankruptcy in the U.S. Bankruptcy Court for the Central District of California. ${ }^{77}$ Smith then filed suit in the bankruptcy case against E. Pierce Marshall; again alleging, as she had in her Texas Probate Court action, that he had tortiously interfered with the fulfillment of his father's promise to her. ${ }^{78}$

Smith's bankruptcy filing demonstrates the ease by which a strategic forum shopper can trump up jurisdiction in a bankruptcy court and thereby engage in a race to the courthouse to try to get a bankiuptcy judge to second-guess a state court judge. The initial judgment for alleged sexual harassment was entered as a default judgment; Smith and the purported victim later settled the suit for an amount that was small enough to, relieve her of any further need of bankruptcy to satisfy her creditors. ${ }^{79}$ In fact, the combination of the initial default judgment and the subsequent settlement raises concerns that the initial suit was manufactured collusively just to create bankruptcy court jurisdiction. And even if not actually a collusive bankruptcy filing, the facts illustrate the ease by which bankruptcy potentially could be manufactured through collusion.

In early March of 1999, the bankruptcy court confirmed Smith's chapter 11 restructuring plan, effectively ending the bankruptcy case. ${ }^{80}$ Nevertheless, even though the chapter 11 case was concluded and the Texas case was about to commence, the bankruptcy court proceeded to adjudicate Smith's tortious interference suit against E. Pierce Marshall. ${ }^{81}$ In October 2000, the Bankruptcy Court determined that E. Pierce Marshall had engaged in discovery abuse and as a sanction, barred him from introducing evidence at trial to contradict Smith's assertions. ${ }^{82}$ After conducting a five-day summary trial and waiting almost a year to issue its decision, in October 2000 the bankruptcy court found in favor of Smith, concluding that E. Pierce Marshall had fraudulently altered his father's trust, and that as a result, "tortiously deprived [Smith] of her expectancy of a substantial inter vivos gift from her deceased husband ....",83 The bankruptcy court reasoned that under its interpretation of Texas law, Marshall's failure to include Smith in his will entitled her to a widow's election of half the community property passing through the estate. ${ }^{84}$ Meanwhile, jury selection was about to begin in the Texas Probate Court case.

${ }^{76}$ Marshall v. Marshall (In re Marshall), 253 B.R. 550, 553-54 (Bankr. C.D. Cal. 2000).

${ }^{77}$ Marshall v. Marshall (In re Marshall), 275 B.R. 5,8 n.3 (C.D. Cal. 2002).

${ }^{78}$ Id. at 23-25.

${ }^{79}$ Cass, supra note 65 , at 3 .

${ }^{80}$ Marshall v. Marshall (In re Marshall), 273 B.R. 822, 825 (Bankr. C.D. Cal. 2002).

${ }^{81}$ In re Marshall, 275 B.R. at 9.

${ }^{82}$ Id.; Marshall v. Marshall (In re Marshall), 253 B.R. 550, 561 (Bankr. C.D. Cal. 2000).

${ }^{83}$ See In re Marshall, 253 B.R. at 561.

${ }^{84}$ See id. at 554 (defining the "new community" as half of the appreciation of J. Howard's assets); id. at 561-62 (calculating damages at half of the community property); 
One month after its initial judgment, the bankruptcy court issued a revised opinion, again resting upon the discovery sanction. ${ }^{85}$ Contrary to the court's initial determination, it now found that Marshall had intended to transfer a substantial portion of his wealth to Smith, but that E. Pierce Marshall had tortiously interfered with that plan by firing the lawyer hired to draft the "catch-all" trust for Smith. ${ }^{86}$ With this new ruling, the bankruptcy court awarded Smith $\$ 449,754,134$ on her Texas-law-based tortious interference claim-relying, in part, on the court's own estimates as to increases in the price of oil. ${ }^{87}$

E. Pierce Marshall appealed these determinations to the U.S. District Court for the Central District of California. ${ }^{88}$ The district court vacated the bankruptcy court's judgment, finding that the Texas law tortious interference lawsuit did not fall within the bankruptcy court's "core" bankruptcy jurisdiction under 28 U.S.C. § $157 .{ }^{89}$ The district court rejected E. Pierce Marshall's argument that it lacked jurisdiction under the "probate exception" to federal jurisdiction, and proceeded to adjudicate the Texas law claims de novo. ${ }^{90}$

In Texas, the probate court proceeded to adjudicate the dispute regarding Marshall's will, including Smith's tortious interference claim against E. Pierce Marshall. ${ }^{91}$ After five months of testimony, a Texas jury returned a verdict upholding the validity of Marshall's estate plan, trust, and will. ${ }^{92}$ The jury rejected all allegations of impropriety, including Smith's tortious interference claim against E. Pierce Marshall..$^{93}$ In December 2001, the Texas Probate Court entered its final judgment, admitting Marshall's will to probate, finding the trust valid, and dismissing Smith's counterclaims against E. Pierce Marshall. ${ }^{94}$

Shortly after the Texas Probate Court entered its judgment, E. Pierce Marshall filed a motion in the U.S. District Court for the Central District of California to dismiss the Texas-law-based probate claims prior to the start of the trial in Santa Ana. ${ }^{95}$ Although the Texas state court proceedings had concluded with a judgment resting on Texas law, the district court in California denied the motion, holding that the probate exception to federal jurisdiction did not apply because the probate exception applied only to the probate of wills. ${ }^{96}$

see also In re Marshall, 275 B.R. at 41 (suggesting that Texas law would have regarded this amount as the community property of the marriage).

${ }^{85}$ Marshall v. Marshall (In re Marshall), 257 B.R. 35 (Bankr. C.D. Cal. 2000).

${ }^{86} \mathrm{Id}$. at 40.

${ }^{87} \mathrm{Id}$.

${ }^{88}$ Marshall v. Marshall (In re Marshall), 264 B.R. 609 (C.D. Cal. 2001).

${ }^{89} \mathrm{Id}$. at 633.

${ }^{90}$ Id. at 619.

${ }^{91}$ Marshall v. Marshall (In re Marshall), 392 F.3d 1118, 1124-25 (9th Cir. 2004).

${ }^{92}$ Id. at $1128-29$.

${ }^{93} \mathrm{Id}$. at $1129-30$

${ }^{94} \mathrm{Id}$.

${ }^{95} \mathrm{Id}$. at 1130 .

${ }^{96} \mathrm{Id}$. 
Three months after the Texas Probate Court entered its judgment, the U.S. District Court entered its own decision on Smith's Texas-law-based tortious interference claim. ${ }^{97}$ Although the district court in Santa Ana acknowledged that Texas courts had never recognized a claim for tortious interference with an "expectancy of an inter vivos gift," it nevertheless determined that it would be the first court to do so under Texas law. ${ }^{98}$ The district court found that Marshall had intended to create a "catch-all" trust for Smith, and that E. Pierce Marshall had tortiously interfered with that plan. ${ }^{99}$ With these findings directly contradicting the findings of the Texas Probate Court jury on the same issues, the district court awarded Smith $\$ 88,585,534.66$ in compensatory and punitive damages. ${ }^{100}$

E. Pierce Marshall appealed the district court judgment, arguing that probate cases were excepted from federal jurisdiction, and that the Full Faith and Credit Act required the district court to give preclusive effect to the Texas Probate Court judgment. ${ }^{101}$ The U.S. Court of Appeals for the Ninth Circuit reversed the district court judgment. ${ }^{102}$ Smith then appealed the case to the Supreme Court. ${ }^{103}$

The Supreme Court reversed the Ninth Circuit's dismissal of Smith's Texas law claim, holding that the probate exception did not permit a state court to grant itself exclusive jurisdiction over a state-law-based claim. ${ }^{104}$ The Court remanded the case on the question as to whether the bankruptcy court had core jurisdiction over the state law claim, and, in turn, whether it had the power to issue final orders in the case. ${ }^{105}$

In short, Marshall $v$. Marshall is the prototype of a new forum-shopping problem in bankruptcy. As a state court proceeding was underway, one of the parties to that proceeding filed a bankruptcy petition 1,500 miles away. After the bankruptcy case had ended, the bankruptcy court then exercised jurisdiction over the state-law-based claims and reached a judgment diametrically opposed to that entered by the state court applying its own law. The ruling was unnecessary both as a matter of administration of the bankruptcy estate and as an expedient to avoid undue delay. The case is particularly strange in that the result in the bankruptcy court case was determined by the imposition of sanctions for the failure to cooperate in an action that the bankruptcy court should not have heard in the first place. As a consequence of hearing the case under these terms, the bankruptcy court reached a result that was almost certainly incorrect on both the law and the facts, as demonstrated by the contrary result in the fully litigated state case.

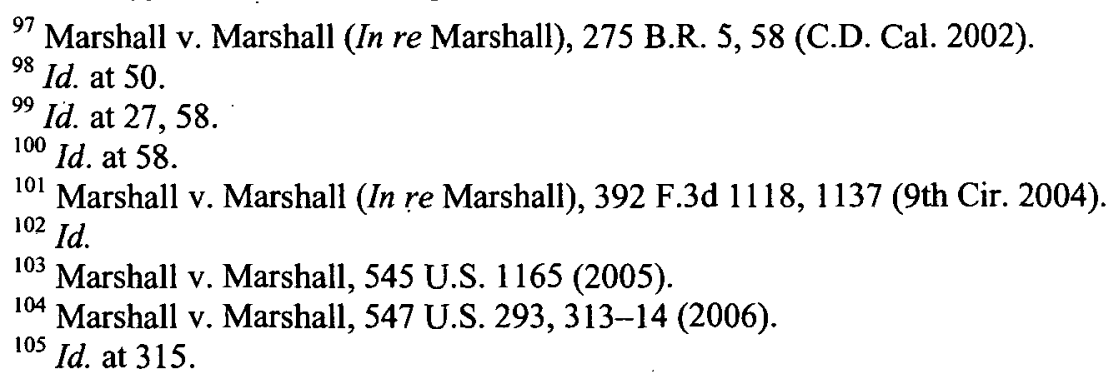


Marshall v. Marshall can accurately be characterized as one dispute between two parties, in two different courts, purportedly applying the same state law but having dramatically different outcomes. ${ }^{106}$

This result is possible, perhaps even likely, if the bankruptcy court jurisdiction over the claim is rendered equal to that of the state court, or an Article III federal court. The conclusive and dispositive effect of final orders governing discovery and sanctions produce a potential, as in Marshall, for dramatically different outcomes with respect to the same dispute. This "final order" question gives rise to the new forum-shopping problem in bankruptcy, and a new question: "When can a bankruptcy court enter final orders?"

\section{THE LIMITS OF BANKRUPTCY JURISDICTION}

The question of forum shopping now turns on whether the bankruptcy court had the power to issue final judgments and orders, such as those sanctioning E. Pierce Marshall and precluding the presentation of evidence. If the bankruptcy court has such a power, then it becomes a parallel universe to that existing in state courts under state law, even when state courts have themselves entered final judgments on the same issues. On the other hand, does determination of a statelaw-based claim require either state court or an Article III federal court?

The answer to this question depends upon statutory construction. Under 28 U.S.C. $\S 157$, bankruptcy judges and courts have final order jurisdiction over matters arising from the public rights established by Congress ${ }^{107}$ pursuant to its authority under the Bankruptcy Clause of the Constitution. ${ }^{108}$ As noted earlier, while the statute bifurcates bankruptcy jurisdiction into core and non-core proceedings, it does not define either category. Instead, it provides a nonexhaustive list of the types of proceedings included in the meaning of "core" proceedings. But this list also includes "other proceedings affecting the liquidation of assets ... or the adjustment of the debtor-creditor ... relationship." 109 In short, it is conceivable that a bankruptcy court, in making the determination as to whether a matter is a "core" proceeding, might rely on this language and sweep into its final order jurisdiction a case wholly reliant upon state law and rights created by it, thereby elevating its powers to those of an Article III federal court.

But even if a bankruptcy court determined that a matter was a "core" matter under $\S 157(b)(2)$, that determination would not be enough to confer final order jurisdiction upon it. In order to have final order jurisdiction, the bankruptcy court must have before it a "core" matter that also either "arises in" or "arises under" a case under title $11 .{ }^{110}$ The distinction may appear to be a subtle one, but it is one of enormous consequence. To read $\S 157$ as conferring final order jurisdiction upon a

${ }^{106}$ Cf. Erie R.R. v. Tompkins, 304 U.S. 64 (1938).

${ }^{107}$ See 28 U.S.C. $\$ 157($ b) (2006).

${ }^{108}$ U.S. CONST, art. I, $\$ 8, \mathrm{cl} .4$.

${ }^{109} 28$ U.S.C. $\S 157(\mathrm{~b})(2)(\mathrm{O})$.

${ }^{110} 28$ U.S.C. $\S 157(a)-(b)(1)$. 
bankruptcy court over any core matter, without more, is to expand bankruptcy jurisdiction beyond its constitutional constraints. It is the "arising in" and "arising under" qualifications on final order jurisdiction that bring bankruptcy courts within the bounds of the constitutional limits of their powers.

To understand why an expansive reading of $\S 157$, without imposing the "arising in" or "arising under" qualifications, might create the new forum-shopping problem, we need to understand how and why the Constitution limits the final order powers of Article I bankruptcy judges.

What makes this core versus non-core determination important for purposes of a discussion of forum shopping is the potential for a litigant to take advantage of the special circumstances surrounding a bankruptcy case that might alter or dramatically change the outcome had the case been litigated in a state court or Article III federal court. The possibility of forum shopping has, for this very reason, long been a concern of legislators and courts confronted with the task of crafting and shaping bankruptcy law. ${ }^{111}$ Bankruptcy jurisdiction, and any statutory provision governing it, can only be understood in light of its history. Modern bankruptcy jurisdiction has its roots in the U.S. Code, title 28 and title 11 (the Bankruptcy Code), and the Supreme Court's ruling in Northern Pipeline Construction Co. v. Marathon Pipe Line Co. ${ }^{12}$

\section{A. The Origins of Modern Bankruptcy Jurisdiction}

\section{Jurisdiction under the Bankruptcy Act of 1898}

The first, lasting bankruptcy law enacted by Congress was the Bankruptcy Act of 1898 (the Act). ${ }^{113}$ The Act was a product of compromise between the interests of agrarian debtors who feared centralized control over debtor-creditor relations, and Northeastern urban bankers, who feared the chaos that persisted when pursuing debt obligations across state lines. ${ }^{114}$ The compromise of the Act was to create a national set of procedures into which the substantive law of the states would be incorporated. ${ }^{115}$ This compromise not only ended the factional logjam that prevented the passage of a bankruptcy bill; it recognized and solved the forum-shopping problem for the very first time.

Although the distinction between procedure and substance under the Act was relatively clear, the jurisdictional scheme was less so. Bankruptcy jurisdiction under the Act was referred to as "summary jurisdiction." 16 This type of jurisdiction was to be distinguished from non-bankruptcy federal or state courts,

${ }^{111}$ See, e.g., Butner v. United States, 440 U.S. 48, 55 (1979).

112458 U.S. 50 (1982).

113 For a history of the short-lived bankruptcy enactments leading up to the Bankruptcy Act of 1898, see Charles Jordan Tabb, The History of the Bankruptcy Laws in the United States, 3 AM. BANKR. INST. L. REV. 5, 12-23 (1995).

${ }_{114}$ See SKEEL, supra note 4, at 39.

115 See Cole, supra note 30 , at 246.

${ }^{116}$ See Katchen v. Landy, 382 U.S. 323, 327 (1966); 1 NORTON, supra note 60, § 4:7. 
which enjoyed "plenary jurisdiction."117 Summary jurisdiction gave bankruptcy courts subject matter jurisdiction with respect to proceedings that were central to the administration of the bankruptcy estate, but only some disputes involving rights or property interests affecting the bankruptcy estate. ${ }^{118}$ The determination as to whether a matter fell within a bankruptcy court's summary jurisdiction rested upon whether the property in question was in the actual or constructive possession of the bankrupted at the time of filing, or whether the relevant third party actually or impliedly consented to the court's jurisdiction. ${ }^{119}$ If the matter did not fall within the bankruptcy court's summary jurisdiction then the "litigant was required to assert the claim by a 'plenary action' in a non-bankruptcy federal or state court.",120

The frequent litigation that arose from this nebulously-defined jurisdiction was among the many forces that led Congress to scrap the entire system with the passage of the Bankruptcy Code. ${ }^{121}$

\section{Jurisdiction under the Bankruptcy Code of 1978}

The passage of the Bankruptcy Code brought sweeping change to the bankruptcy system. Congress replaced the office of bankruptcy referee with that of bankruptcy judge. ${ }^{122}$ For political reasons, however, Congress declined to make the new bankruptcy judges Article III judges, with all of the protections that portion of the Constitution affords. ${ }^{123}$ Instead, Congress created the new office of bankruptcy judge and concomitant courts under the powers conferred upon it by Article I, Section 8 of the Constitution. ${ }^{124}$ These Article I judges enjoyed responsibilities that far exceeded those of the former bankruptcy referees; they exercised plenary jurisdiction to hear any and all cases associated with bankruptcy proceedings. ${ }^{25}$

Despite their sweeping jurisdictional range, these new Article I bankruptcy judges were not appointed by the president, upon the advice and consent of the Senate, nor were they to serve for life during good behavior. ${ }^{126}$. Unlike their Article

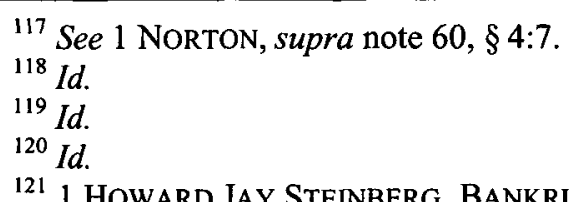
that it has been estimated that as much as $50 \%$ of all litigation under the 1898 Act concerned whether a matter was within the bankruptcy court's summary jurisdiction (citing Thomas S. Marion, Core Proceedings and "New" Bankruptcy Jurisdiction, 35 DEPAUL L. REV. 675, 677 (1986)).

${ }^{122}$ See 1 COLLIER ON BANKRUPTCY I 2.01 (16th ed. 2009).

${ }^{123}$ The Article III federal judiciary vehemently opposed the dramatic expansion of its ranks, as would have been the case had the new bankruptcy judges been afforded Article III status. See SKEEL, supra note 4, at 157-59.

${ }^{124}$ Article I of the Constitution details the powers of Congress, and Article 8 lists those powers, including the power to establish "uniform Laws on the subject of Bankruptcies throughout the United States." U.S. CoNST. art. I, § 8, cl. 4.

${ }^{125} 28$ U.S.C. $\S 157(2006)$.

${ }^{126}$ See 28 U.S.C. § 152(a)(1) (2006). 
III brethren, bankruptcy judges were appointed by the United States Court of Appeals for the Circuit in which they sat, and then only for a term of fourteen years. ${ }^{127}$ Nevertheless, under the system established by the Bankruptcy Code, the new Article I bankruptcy judges could hear and decide a virtually unlimited spectrum of title 11 cases. ${ }^{128}$

\section{The Unconstitutional Bankruptcy Code: Marathon and the Emergency Rule}

This long arm of bankruptcy jurisdiction was exercised after the passage of the Bankruptcy Code until it was sharply slapped into restraint in 1982. As noted above, in Marathon, the Supreme Court struck down the Bankruptcy Code and its jurisdictional scheme as unconstitutional because as a non-Article III court, a bankruptcy court could not constitutionally be vested with jurisdiction to decide the state law contract claim raised in the case. ${ }^{129}$ Since there was no way to excise the unconstitutional grant of authority to bankruptcy courts from the rest of the Bankruptcy Code without rewriting it completely, the Court struck down the entire code as unconstitutional. ${ }^{130}$

The Court's ruling in Marathon plunged the entire bankruptcy system into chaos. Bankruptcy cases already in the system had to be administered, but could not be administered under unconstitutional legislation. To address the backlog of pending bankruptcy cases, as well as those likely to be filed while awaiting congressional action to enact a new code, the Judicial Conference of the United States met to craft an interim solution.

The federal judiciary adopted an "Emergency Rule," to operate as a rule of court, to administer bankruptcy cases. ${ }^{131}$ Under the Emergency Rule, adopted by all of the U.S. District Courts after the 1982 Marathon decision, all bankruptcy cases were to be filed in the district court, an Article III court. ${ }^{132}$ The Article III district court could then refer the matter to a bankruptcy judge operating as a type of special master to the district court. ${ }^{133}$ As a special master, the bankruptcy court could not make final determinations about the types of matters over which Article III reserves the judicial power of the United States. ${ }^{134}$ Instead, the Article I special master could only make proposed findings of fact and determinations of law. ${ }^{135}$

${ }^{127}$ Id.

${ }^{128}$ See 1 NORTON, supra note $60, \S 1: 8$.

${ }^{129}$ N. Pipeline Constr. Co. v. Marathon Pipe Line Co., 458 U.S. 50, 87 (1982).

${ }^{130}$ See id.; see also id. at 91-92 (Rehnquist, J., concurring) ("I would, therefore, hold so much of the Bankruptcy Act of 1978 as enables a Bankruptcy Court to entertain and decide Northern's lawsuit over Marathon's objection to be violative of Art. III of the United States Constitution.").

${ }^{131}$ MODEL EMERGENCY BANKR. RULE (a) (1982), reprinted in BANKRUPTCY CODE, RULES AND FORMS, at XV (West 1983).

${ }^{132}$ See id. at (b).

${ }^{133}$ See id. at (c).

${ }^{134}$ See id. at (d).

${ }^{135}$ Id. 
These proposed findings must then be considered by the district court, which then must review these findings and determinations de novo. ${ }^{136}$ Only district courts, courts of appeals, and the Supreme Court, as Article III courts, are vested with the authority to enter final orders with respect to matters reserved for the judicial power under the Constitution. ${ }^{137}$

The bankruptcy system operated under the Emergency Rule and its special master reference system for two years while Congress mulled the Marathon decision and its implications. One possible solution was to make all bankruptcy judges Article III judges, but Congress flatly rejected that proposal. ${ }^{138}$ Instead, Congress noted that the Emergency Rule adopted by the federal district courts appeared to operate quite well, despite its awkward jurisdictional arrangement. In 1984, Congress enacted the present jurisdictional scheme for bankruptcy by adopting the Emergency Rule as a permanent solution to the constitutional questions surrounding bankruptcy jurisdiction. ${ }^{139}$

\section{Modern Bankruptcy Jurisdiction}

The present structure of bankruptcy jurisdiction cannot be understood without understanding the three statutory provisions that give it life. Title 28 of the U.S. Code governs jurisdictional matters, and the three provisions allocating judicial power under it are $\S \S 151,157$, and 1334. These three provisions establish a jurisdictional structure under which bankruptcy courts are a unit of the district court, supervised and administered by the district court. Bankruptcy judges, however, are not Article III district court judges, but are instead designated to hear cases referred to them by the district court. All U.S. district courts, by operation of local rules, automatically refer bankruptcy petitions filed with their respective clerk of court's office to the district's bankruptcy court. ${ }^{140}$ This "automatic reference" system is loosely supervised by the judges of the district court, and complies with the constitutional requirement that the Article III district courts be the courts of original jurisdiction. ${ }^{141}$

${ }^{136}$ See id. at (e).

${ }^{137}$ N. Pipeline Constr. Co. v. Marathon Pipe Line Co., 458 U.S. 50, 80-81 (1982).

138 Vern Countryman, Scrambling to Define Bankruptcy Jurisdiction: The Chief Justice, the Judicial Conference, and the Legislative Process, 22 HARV. J. ON LEGIS. 1, 2933 (1985).

${ }^{139}$ See id. at 35.

${ }^{140}$ On two noteworthy occasions, the U.S. District Court for the District of Delaware withdrew the automatic reference to its bankruptcy court in order to stem the explosion of corporate filings in Delaware, and in response to criticism that the Delaware bankruptcy judges were encouraging forum-shopping by corporate debtors. See Marcus Cole, "Delaware is Not a State": Are We Witnessing Jurisdictional Competition in Bankruptcy?, 55 VAND. L. REV. 1845, 1850-58 (2002); see generally id. (examining the explanations offered by lawyers and judges for the rise in Delaware bankruptcy cases).

${ }^{141}$ Id. at 1852. 
With the automatic reference system, the bankruptcy judge today is similar to the "special master" under the Emergency Rule. In fact, the Supreme Court suggested in Marathon that to the extent that the bankruptcy judge was acting as something more than a special master-such as by making final orders rather than findings of fact to be reviewed on appeal-this would be constitutionally infirm. ${ }^{142}$ For this reason, a withdrawal of the automatic reference renders the core versus non-core distinction irrelevant, because an Article III judge can hear and issue final orders in any case. ${ }^{143}$ Moreover, because the automatic reference is rarely withdrawn, the distinction between core proceedings and non-core proceedings is critically important. This is because, under 28 U.S.C. $\$ 157(b)(1)$, Article I bankruptcy judges have the power to issue final orders only in core proceedings. ${ }^{144}$

The determination as to whether a matter is a core or non-core proceeding also affects the standard of review exercised by the district court. Under 28 U.S.C. $\S 158(a)$, district courts exercise ordinary appellate jurisdiction over final orders entered by a bankruptcy court with respect to core proceedings. ${ }^{145}$ Ordinary appellate jurisdiction for core matters carries with it deference to the findings of the court below. ${ }^{146}$ For non-core matters, by contrast, the appellate courts apply de novo review. ${ }^{147}$ Thus, the determination of whether a matter is core or non-core impacts the scrutiny that Article III judges apply on appeal as well as the finality of the bankruptcy court's ruling.

\section{In re Wood and Constitutional Core Jurisdiction}

Whether a matter is a core proceeding, and therefore worthy of deference upon review, is perhaps the most important question confronting any court concerned about the new forum-shopping problem. In the case of In re Wood, the Fifth Circuit explored the limits that Marathon places. on the broad grant of bankruptcy jurisdiction implied by the statutory framework. ${ }^{148}$

Wood involved a dispute between the stockholders of a closely held medical clinic. ${ }^{149}$ When married directors filed for bankruptcy, another stockholder disputed distributions made to one of the debtors. ${ }^{150}$ The bankruptcy court ruled that the matter was a core matter, falling within the bankruptcy court's jurisdiction, which the defendants appealed. ${ }^{151}$ The district court ruled that the bankruptcy court lacked subject matter jurisdiction over the dispute and thus had neither core nor

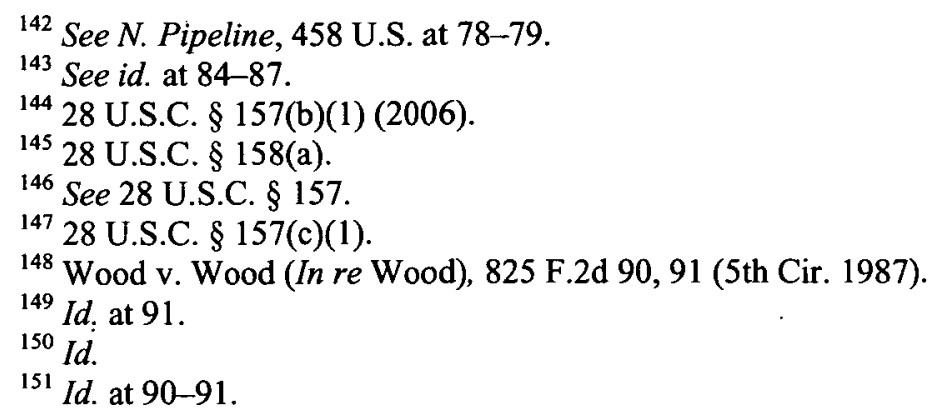


non-core jurisdiction over the state-law-based dispute-the plaintiffs appealed to the court of appeals. ${ }^{152}$ The Fifth Circuit ruled that both lower courts erred. ${ }^{153}$

The Wood court explained that bankruptcy jurisdiction under 28 U.S.C. $\$ 157$ was neither as broad as the bankruptcy court had hoped, nor as narrow as the district court had envisioned; instead, it was somewhere in between. ${ }^{154}$

To understand the jurisdiction of bankruptcy courts, we need to understand the statutory provisions from which that jurisdiction draws life. As the Wood court explained, 28 U.S.C. $\$ 1334$ (b) lists four types of matters over which bankruptcy courts have jurisdiction:

1. "cases under title 11, ,

2. "proceedings arising under title $11, "$

3. proceedings "arising in" a case under title 11 , and

4. proceedings "related to" a case under title 11 . $^{155}$

The Wood court noted that "[t]he first category refers merely to the bankruptcy petition itself." 156 The difficulty stems from the meaning of the other types of matters listed. Since there is very little legislative history of the Bankruptcy.Amendments of 1984 from which an interpretation might be gleaned, the Wood court turned to the legislative history of the prior jurisdictional structure. ${ }^{157}$ That made sense, since the language of $\$ 1334(\mathrm{~b})$ "was taken verbatim from section 1471 of the 1978 Act." 158 That history revealed that Congress was concerned with the inefficiencies of piecemeal adjudication of matters affecting the administration of bankruptcy cases, and wanted to marshal all related matters into one forum. ${ }^{159}$ Accordingly, the Wood court held that bankruptcy jurisdiction, under $\S 157$, is necessarily broad, encompassing any proceedings having any "conceivable effect on the estate." 160 This meant that the district court erred when it held that the state-based contract claim was outside the jurisdiction of the bankruptcy court. ${ }^{161}$

This holding, however, did not affirm the bankruptcy court's jurisdictional determination either. Although bankruptcy jurisdiction is necessarily broad, it does not follow that the powers of the bankruptcy court are likewise broad. The Wood court explained that the Marathon decision that prompted the 1984 amendments to the Bankruptcy Code meant that an Article I bankruptcy judge does not have

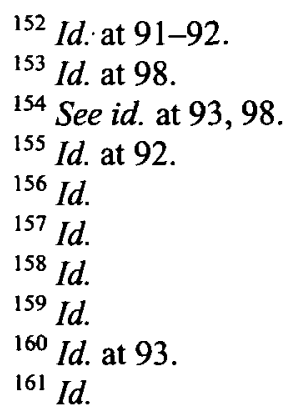


powers coextensive with those enjoyed by Article III judges. ${ }^{162}$ To hold otherwise would be "a result contrary to the ostensible purpose of the 1984 Act."163

To read the 1984 amendments in a way that conformed to the holding of Marathon, the Wood court articulated a more modest vision of bankruptcy jurisdiction. Bankruptcy judges, as Article I judges, could hear non-core proceedings; they could not, however, issue final orders or judgments in those proceedings. ${ }^{164}$ Instead, their power in such matters was limited to submitting "proposed findings of fact and conclusions of law to the district court."165

By holding that bankruptcy courts had more limited powers when hearing cases related to, but independent of, bankruptcy-created rights, the Wood court refused to read 28 U.S.C. $\$ 157(\mathrm{~b})(2)(\mathrm{O})$ as expansively as the language might imply. To read this subsection expansively, according to the court in Wood, would cause "the entire range of proceedings under bankruptcy jurisdiction [to] fall within the scope of core proceedings." 166 Such a result would ignore the constitutional limits recognized by Marathon, and Congress's responsibility to bring bankruptcy legislation in line with its holding.

\section{THE LOGICAL LIMITS OF BANKRUPTCY JURISDICTION}

Strong policy considerations, reflected in the plain language of the jurisdictional statutes governing bankruptcy courts, support the Supreme Court's concern in Marathon that certain matters are properly heard by an Article III judge (or the state equivalent) rather than by a bankruptcy judge. The framers showed great care in designing the Article III federal judiciary, and particularly the structural protections for individual rights and the effective administration of justice embedded therein, including life tenure and undiminishable remuneration. ${ }^{167}$ Article I bankruptcy judges, by contrast, lack both of these protections. This distinction is not trivial-the framers plainly understood that the protections of judicial independence and competence were essential to the proper and unbiased administration of justice.

\section{A. The Plain Meaning of Sections 157(b)(1) and (2)}

The natural reading of $\S 157(\mathrm{~b})$, in fact, both vindicates the plain meaning of the statute while also addressing and resolving forum-shopping concerns. Section 157 (b)(1) can be interpreted as meaning something it very clearly says that in order for a bankruptcy court to exercise final order jurisdiction over a matter (i.e., jurisdiction to enter a final order subject only to ordinary appellate review versus recommended findings of fact and conclusions of law), the matter must be a "core

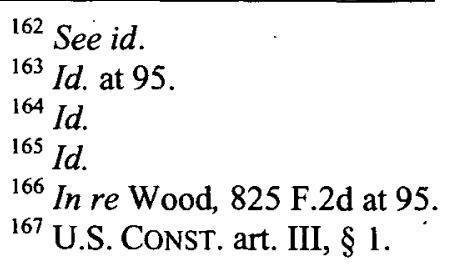


proceeding[] arising under title 11 , or arising in a case under title $11 . " 168$ Thus, under $\S 157(b)(1)$, the matter must be either (1) a core proceeding that arises under title 11 , or (2) a core proceeding that arises in a case under title 11 .

In other words, it is not sufficient for purposes of $\S 157(b)(1)$ that a matter is a core proceeding; the party asserting bankruptcy jurisdiction must demonstrate not only that the matter is "core" within the meaning of $\S 157(b)(2)$, but also that it "arises under" or "arises in" a case under title 11. Such a reading limits the breadth of the definition of "core" matters in 157(b)(2) to proper constitutional dimensions by requiring that the matter must also "arise under" or "arise in" within the meaning of $\S 157(b)(1)$.

This reading is also supported by at least two canons of statutory construction. First, it is supported by the canon of not treating words of a statute as superfluous. ${ }^{169}$ Section $157(b)(1)$ does not grant jurisdiction over matters that are core; it grants jurisdiction over core proceedings that "arise under" or "arise in" title 11. Limiting the analysis to whether a matter is core reads the "arise under" or "arise in" text out of the statute. Section 157(b)(2) defines core proceedings but does not define the terms "arising under" or "arising in." These terms, however, have established meanings as the Wood case describes. ${ }^{170}$

Second, this reading is supported by the canon that, where possible, statutes should be interpreted to avoid constitutional conflicts. ${ }^{171}$. An expansive reading of $\S$ $157(b)(1)$ as conferring jurisdiction broadly over all core matters runs smack into the Marathon problem of giving bankruptcy judges authority to render final judgments on private right controversies, such as the state-law claims in Marshall. A more restrictive reading of $\S 157(\mathrm{~b})(1)$, limited to core matters that either "arise under" or "arise in," avoids the constitutional problem by denying the bankruptcy courts authority to enter final judgments in such cases.

In Marshall, a plain reading of the statute would have prevented the attempted forum shopping, or dramatically mitigated its effects. Because the bankruptcy court would have lacked jurisdiction to enter a final judgment under such a reading, its $\$ 474$ million judgment would not have been enforceable as a final judgment otherwise would have been. At most, the bankruptcy court's opinion would have been an unenforceable recommended ruling. Because the $\$ 474$ million judgment could not have been be enforced, there would have been no need to bond it over to prevent enforcement. ${ }^{172}$ But even if the bankruptcy judge's

${ }^{168} 28$ U.S.C. $\$ 157(b)(1)$.

${ }^{169}$ Lamie v. U.S. Tr., 540 U.S. 526, 536 (2004); Negonsott v. Samuels, 507 U.S. 99, 105 (1993).

${ }^{170}$ See 825 F.2d at $96-97$.

${ }^{171}$ See Edward J. DeBartolo Corp. v. Fla. Gulf Coast Bldg. \& Constr. Trades Council, 485 U.S. 568, 575 (1988); see also United States v. Sec. Indus. Bank, 459 U.S. 70, 78 (1982) (ruling that no bankruptcy law should be read to eliminate property rights which existed before the law was enacted); Andrus v. Glover Constr. Co., 446 U.S. 608, 618-19 (1980) (ignoring constitutional grounds for a judgment where adequate statutory grounds for that judgment existed).

${ }^{172}$ See Marshall v. Marshall, 547 U.S. 293, 303 (2006). 
opinion was only a recommendation, the bond itself was so large in Marshall that the bankruptcy court's ruling effectively amounted to a final judgment because it would have been economically unfeasible to appeal the ruling. In such a situation, the party against whom it is entered has to capitulate simply because of the sheer magnitude of the liability and the inability to bond it over.

Ultimately, if the bankruptcy court in Marshall lacks the power to enter final orders, the district court bears that responsibility. Again, this would have made an enormous difference in Marshall. The fact that the district judge entered a final judgment almost $\$ 400$ million less than the bankruptcy judge's award dramatically illustrates this point. ${ }^{173}$

The bankruptcy court in Marshall believed that it could avoid constitutional and statutory issues because E. Pierce Marshall filed a proof of claim in the case, ${ }^{174}$ but the happenstance that Smith's suit technically arose as a counterclaim to a proof of claim cannot convert that lawsuit into a core proceeding. If Smith had initiated a claim for tortious interference with a contract against E. Pierce Marshall, that plainly would fall outside of the bankruptcy court's "core" jurisdiction. That it instead arose as a permissive counterclaim-unrelated to the validity of the underlying proof of claim-cannot change its essential nature as a non-core proceeding. If the claim was a compulsory counterclaim, then an argument could be made (although it would be doubtful) that it was sufficiently intertwined with the resolution of the proof of claim that it could be a core proceeding. But the claim in Marshall was not a compulsory counterclaim because it did not involve adjudication of the same essential facts as the proof of claim. ${ }^{175}$ The definition of a core versus non-core proceeding is a question of judicial power that parties cannot create by private action, any more than they can create federal subject matter jurisdiction by private action. ${ }^{176}$ Nor is "core" status an affirmative defense that can be waived by filing a proof of claim. ${ }^{177}$ Thus, the mere happenstance that Smith's claim arose as an unrelated counterclaim to a filed proof of claim cannot convert the proceeding into a core proceeding when the underlying claim itself could not have been core in the first instance. ${ }^{178}$

Similarly, because the bankruptcy court lacked jurisdiction to enter a final judgment, its judgment was not entitled to res judicata or collateral estoppel effect. This permits any intervening non-bankruptcy court's final judgment (such as the Texas Probate Court) to take precedence. In Marshall, this would have meant that the judgment of the Texas Probate Court would have had preclusive effect on the bankruptcy proceedings in California.

${ }^{173}$ See supra notes 87,100 and accompanying text.

${ }^{174} I d$. at 300 .

${ }_{175}^{17}$ Marshall v. Marshall (In re Marshall), 264 B.R. 609, at 630-31 (C.D. Cal. 2001).

${ }^{176}$ Although the parties may consent to a final judgment by a bankruptcy judge in a non-core action.

${ }^{177}$ See Piombo Corp. v. Castlerock Props. (In re Castlerock Props.), 781 F.2d 159, 162-63 (9th Cir. 1986); In re Marshall, 264 B.R. at 625.

${ }_{178}$ See Dunmore v. United States, 358 F.3d 1107, 1115 (9th Cir. 2004). 
Under federal statute, state judicial proceedings "shall have the same full faith and credit in every court within the United States . . . as they have by law or usage in the courts of such State ... from which they are taken." ${ }^{179}$ In turn, the preclusive effect of a state-law judgment is established by the state's law governing preclusion. ${ }^{180}$ It is well-established that issue preclusion principles apply in bankruptcy proceedings. ${ }^{181}$ In this case, the denial of Smith's claim by the Texas court plainly would have had a preclusive effect in Texas state court, and hence, in bankruptcy court as well. ${ }^{182}$ Under Texas law, Smith's tort claims arising from the will contest would be precluded. ${ }^{183}$

Providing deference to Texas courts in interpreting and applying its own laws is good sense. The need for swiftness and finality in bankruptcy court proceedings often necessitates compromise of other judicial values, such as thoroughness and accuracy. Yet, these are compromises to be tolerated where necessary, not glorified as a matter of course. Where such compromises are unnecessary, they should be avoided in favor of superior processes. Texas courts have an obvious comparative expertise in adjudicating disputes that arise under Texas law. Permitting the Texas case to continue to resolution would have only minimally delayed the resolution of Smith's bankruptcy case. Moreover, rather than deferring to the superior expertise of Texas courts, the Los Angeles bankruptcy judge in Marshall engaged in freelance legal interpretation of Texas law, making pathbreaking, unprecedented determinations of Texas law. The Texas Probate Court conducted a five-month jury trial with dozens of witnesses (including six days of testimony from Ms. Smith) before concluding that the millions of dollars in gifts that Marshall bestowed upon his bride were the full extent of his intended generosity, and dismissed Smith's charge that she had been defrauded out of a larger share of Marshall's estate. ${ }^{184}$ By contrast, the federal bankruptcy judge awarded her a total of $\$ 474$ million (after a five-day court hearing), which was later reduced to approximately $\$ 88$ million on appeal (after another summary hearing). ${ }^{185}$

${ }^{179} 28$ U.S.C. $\$ 1738$ (2006).

${ }^{180}$ Marrese v. Am. Acad. of Orthopedic Surgeons, 470 U.S. 373, 380 (1985).

${ }^{181}$ See Grogan v. Garner, 498 U.S. 279, 284 (1991).

182 See Garner v. Lehrer (In re Garner), 56 F.3d 677, 679-81 (5th Cir. 1995) (citing Bonniwell v. Beech Aircraft Corp., 663 S.W.2d 816, 818 (Tex. 1984)), abrogated on other grounds by Caton v. Trudeau (In re Caton), 157 F.3d 1026, 1030 (5th Cir. 1998); IngersollRand Co. v. Valero Energy Corp., 997 S.W.2d 203, 206-07 (Tex. 1999).

${ }^{183}$ See Thompson v. Deloitte \& Touche, L.L.P., 902 S.W.2d 13, 16 (Tex. App. 1995); Neill v. Yett, 746 S.W.2d 32, 35-36 (Tex. App. 1988). The district court in Marshall $v$. Marshall held that Smith's claims were not precluded by Texas law, but this was premised on the idea that the Texas judgment was not final at the time the bankruptcy court's judgment was entered. In re Marshall, 271 B.R. 858, 864-66 (C.D. Cal. 2001). Had the probate court's judgment been final before the bankruptcy court acted, there seems to be little doubt that it would have had preclusive effect over her claims.

${ }^{184}$ See Marshall v. Marshall (In re Marshall), 273 B.R. 822, 826 (Bankr. C.D. Cal. 2002).

${ }^{185}$ Id. at 825; In re Marshall, 275 B.R. 5, 58 (C.D. Cal. 2002). 
In short, cases such as Marshall underlay the logic of Marathon. Bankruptcy judges unquestionably are highly competent, skilled professionals, as are administrative judges, immigration judges, magistrate judges, and other nonArticle III judges. Nonetheless, these judges may lack the broader perspective and independence that Article III guarantees, including recognition of the important values of comity between the state and federal judicial systems. Marathon requires that the cumbersome process and formal protections of Article III be followed, even where it seems unnecessary, as it may appear to be in many situations. Nonetheless Article III oversight is required precisely for situations such as Marshall when judicial self-restraint breaks down. The guarantee of Article III review before such matters becomes final is a sort of "backstop" when Article I courts go awry, as a result of parochialism or otherwise. Congress is entitled to create rights under the Bankruptcy Code and have them enforced by bankruptcy judges - Congress does not, however, have the same authority with rights that arise outside the Bankruptcy Code. Section 157 strikes this balance by treating bankruptcy court decisions as nonfinal recommendations when pertaining to noncore matters. While this balance may seem overinclusive in many situations, that is what both the statute and the Constitution require.

\section{B. Policies Underlying Article III and the Constitutional Limitations of the Bankruptcy Bench}

Article III establishes a particular, albeit an admittedly imperfect, incentive structure for judges exercising judicial power. In Federalist 78, Alexander Hamilton referred to the judiciary as the "least dangerous" branch of government, because it held the least capacity to infringe upon individual constitutional rights. ${ }^{186} \mathrm{He}$ reasoned that its power to do harm was limited to the authority of its judgments. ${ }^{187}$ This characterization of the judiciary turned, in part, upon Hamilton's vision of an independent judiciary. To promote judicial independence, Hamilton insisted that it was necessary that judges serve during good behavior, and as explained in Federalist 79, without risk to their fiscal support, ${ }^{188}$ because "the power over a man's subsistence amounts to a power over his will.",189

Article III prevents certain considerations from influencing the judgment of judges. Judges and courts created pursuant to Congress's authority under Article I, by contrast, lack these protections. Even when parties consent to jurisdiction, some courts have recently limited the decision-making authority of Article I courts under the Constitution. ${ }^{190}$ There are several notable differences between Article I and Article III judges.

${ }^{186}$ The Federalist No. 78 (Alexander Hamilton).

${ }^{187} \mathrm{Id}$.

188 THE FEDERALIST No. 79 (Alexander Hamilton).

${ }^{189}$ Id.

${ }^{190}$ See United States v. Johnston, 258 F.3d 361, 366-67 (5th Cir. 2001) (limiting the authority of Article I magistrate judges to find district court determinations in criminal proceedings under 28 U.S.C. $§ 2255$ unconstitutional). 
First, bankruptcy cases are often more abbreviated than non-bankruptcy proceedings. Bankruptcy judges tend to be more sensitive to the typically limited resources at issue in bankruptcy, which may give rise to more streamlined, summary processes. As noted, this is an accommodation to the needs of speedy and final resolution in bankruptcy, but it is not ideal when no such haste and informality is necessary. There is no reason to substitute the summary proceedings of bankruptcy courts when a more thorough and accurate process is available with minimal delay.

Second, bankruptcy judges are appointed by the United States Court of Appeals for the circuit in which they sit, and not by the president upon the advice and consent of the Senate. Bankruptcy judges serve for a limited term of fourteen years, although they may be reappointed. ${ }^{191}$ The process for reappointment of bankruptcy judges, however, is highly opaque and depends on currying favor with the local bankruptcy bar. In general, of course, local bankruptcy lawyers are going to prefer judges who assert their jurisdiction authority broadly, thereby bringing major high-profile - and large-fee generating_-cases (such as Marshall) to their district. ${ }^{192}$ Furthermore, unlike Article III judges who serve for life subject to their "good Behaviour" and cannot have their salary reduced during their time in office, ${ }^{193}$ bankruptcy judges may be removed for "incompetence, misconduct, neglect of duty, or physical or mental disability." of Article III judges relative to Article I judges was a cornerstone of the Supreme Court's decision in Marathon. ${ }^{195}$

All of these characteristics could conceivably cause the incentive structure of bankruptcy judges to differ in unfavorable ways from that of Article III judges. Term judges could be seeking reappointment, promotion to an Article III judgeship, fame for purposes of post-judicial employment, or other goals unrelated to an unbiased judgment of the cases before them. ${ }^{196}$ Scholars have argued that bankruptcy judges have an incentive to compete to hear high-profile cases even

${ }^{191}$ One study estimates that approximately $8 \%$ of bankruptcy judges were formally denied reappointment for a second term, but that the percentage may be as high as $26 \%$ when considering those who appear to have had reappointment denied informally or were induced to retire. See Judith Resnik, "Uncle Sam Modernizes His Justice": Inventing the Federal District Courts of the Twentieth Century for the District of Columbia and the Nation, 90 GEO. L.J. 607, 675 (2002).

${ }_{192}$ See Zywicki, Corrupting, supra note 15 , at $1180-85$.

${ }^{193}$ U.S. CONST. art. III, $\S 1$.

19428 U.S.C. $\$ 152(\mathrm{e})(2006)$.

${ }^{195}$ N. Pipeline Constr. Co. v. Marathon Pipe Line Co., 458 U.S. 50, 60-61 (1982). Some commentators have argued that the Supreme Court's concern about the independence of bankruptcy judges is overstated. See Plank, supra note 27, at 620-29.

196 See Resnik, supra note 191, at 672-73. Resnik notes that it has become increasingly common for Article I bankruptcy and magistrate judges subsequently to be promoted to district and appellate judgeships. 
when those cases and the justice system would benefit from having those cases heard elsewhere. ${ }^{197}$

And while bankruptcy judges possess the expertise essential to the efficient operation of the bankruptcy system, their narrow focus and specialized jurisdiction may blind them to the larger social and legal context in which they operate, causing them to overweigh bankruptcy concerns and policies relative to other social, economic, and judicial values. Supervision by Article III judges of general jurisdiction provides a broader perspective on such issues, thereby counterbalancing a tendency toward a parochial "bankruptcy-centric" perspective that can arise and lead bankruptcy judges to undervalue other important systemic and substantive values of the legal system. The accommodation of comity for state courts, for instance, is reflected in a variety of limits on the power of federal courts to resolve disputes grounded in state law, such as limitations on diversity jurisdiction and the highly circumscribed grounds for pendent jurisdiction over state-law claims. Various abstention doctrines further illustrate this principle of deference to state courts in matters of state law.

Bankruptcy jurisdiction, by contrast, is very broad as a matter of statutory grant. And, as the Supreme Court held in the Marshall appeal in narrowly construing the probate exception to the bankruptcy laws as a matter of plenary power, bankruptcy courts must have broad power to resolve matters affecting the administration of the estate. ${ }^{198}$ But that a broad grant of jurisdiction may be necessary does not mean that bankruptcy judges should interfere in every dispute that could conceivably affect the administration of an estate. Rather, it highlights the fundamental question raised by the bankruptcy judge's actions in Marshallthe crucial need for self-restraint by bankruptcy judges to respect other values in the American legal system; such as comity for other actors and the prevention of improper forum shopping. Where self-restraint is lacking and bankruptcy judges overreach to address issues that fundamentally relate to the private rights of individuals rather than the timely administration of the bankruptcy estate, and unduly infringes on state court interpretations of their own laws-the constitutional and statutory scheme renders these judgments advisory only, not final orders. Indeed, the Constitution itself compels this.

More fundamentally, it is crucial to enforce the boundary between the authority of Article I and Article III judges to prevent Congress from sidestepping the structural protections created by the Constitution by assigning authority to Article I judges to resolve issues properly reserved to Article III judges. Similarly, appellate courts must enforce this boundary to prevent circumvention by Congress or judges such as essentially interpreting private rights by recharacterizing them as public rights or inherent judicial powers. ${ }^{199}$

197 See LYNN M. LoPUCKI, COURTING FAILURE: How COMPETITION OF BIG CASES IS CORRUPTING THE BANKRUPTCY COURTS 20 (2005).

${ }^{198}$ See Marshall v. Marshall, 547 U.S. 293, 311 (2006) (limiting the probate exception to property in the custody of a state court).

${ }^{199}$ See, e.g., Resnik, supra note 191, at 668-69. 
Whatever the rationales, both the framers and the Supreme Court have recognized the importance of the Article III framework for reliably unbiased and authoritative adjudication of disputes. The outcome of Marshall v. Marshall provides an instructive example of the ways in which the incentive structure associated with Article I might dramatically affect the outcome of a dispute rooted in state law. For instance, the bankruptcy judge in the case held what has been characterized as a press conference in open court, fielding questions from the media. ${ }^{200}$ Of course, the media attention was largely a product of the celebrity status of the debtor, Anna Nicole Smith. It may not be unusual for a bankruptcy judge to field questions from the press in open court-although the authors have never heard of it-but it would be naive to suggest that such behavior was unrelated to the prominence of the debtor. Many cases, both in district as well as in bankruptcy court, receive substantial media attention, but the judge's behavior in catering to and apparently seeking this attention is nonetheless unusual.

Second, the court in Marshall issued discovery sanctions upon the lesscelebrated party in the case, sanctions that were ultimately overturned on appeal, but were nevertheless dispositive in establishing the factual predicate upon which legal determinations in favor of the celebrity debtor were reached. While sanctions are occasionally overturned, when coupled with other questionable judicial conduct their severity and conclusory nature undermine the authority underlying the exercise of judicial power in the case.

A third example of behavior uncharacteristic of Article III judges is less obvious, but telling. In Marshall, the Texas Probate Court jury handed down its findings after five months of deliberations, based upon determinations of Texas law made by a Texas court. ${ }^{201}$ Nevertheless, the bankruptcy court in Marshall, refused to give deference to the state court adjudication already concluded; instead, the bankruptcy court thought it was an appropriate use of judicial and debtor resources to adjudicate the dispute anew, with limited evidence, all the while making pathbreaking, unprecedented determinations of Texas law. ${ }^{202}$ While the court arguably was under no obligation to abstain from the matter, it unarguably was under no obligation to decide the matter either, and the arguments for refusing to abstain well after the close of the underlying bankruptcy case are unpersuasive at best. At worst, they appear to stem from the court's dissatisfaction with the outcome of the state court proceedings.

There is no reason to believe that Congress or the Court in Marathon intended the perverse incentives created by the bankruptcy judge's actions in Marshall. Under Marshall, every probate dispute could be swept into warring judicial processes to be manipulated by savvy bankruptcy filers. There is no reason to

${ }^{200}$ Brief for Respondent at 6 \& n.7, Marshall v. Marshall, 547 U.S. 293 (2006) (No. 04-1544) (noting that at one point, a reporter from Newsweek magazine took the podium and posed questions regarding the case).

${ }^{201}$ See Marshall v. Marshall, 547 U.S. 293, 302 (2006).

${ }^{202}$ Marshall v. Marshall (In re Marshall), 253 B.R. 550, 559 (Bankr. C.D. Cal. 2000) (specifying the elements of a cause of action for tortious interference with an expectancy of inheritance based on that used by other jurisdictions). 
believe that, in establishing the jurisdiction of the federal bankruptcy courts, Congress intended for the resolution of multi-billion dollar probate disputes to turn on the relative speed by which they are resolved, rather than the thoroughness, accuracy, and expertise of the court hearing it. In fact, upon learning of the determination of the California Bankruptcy Court to rush forward with its trial, Judge Mike Wood, who presided over the probate trial in Texas state court, told the attorneys, "If this were a bankruptcy court in Texas, that judge would send you back to probate court and say, 'Let me know when you are finished.",203 Such deference is typical in such situations, which explains why the bankruptcy judge's behavior in this case can be seen as so unusual.

Rather than relying on Texas courts to administer Texas law in a forum with Texas witnesses and judges, a federal bankruptcy judge over a thousand miles away issued an order after a summary hearing and a series of questionable interpretations of Texas probate law. Marshall potentially raises the specter of such a race to the courthouse in every probate case-and the principle potentially extends beyond probate to all issues of traditional state law including tort, contracts, and property. Bankruptcy law and state probate law have peacefully coexisted for over a century and it is difficult to believe that Congress intended such a radical departure from this harmony, especially when doing so would create such perverse policy results with little obvious advantage. ${ }^{204}$

Professor Troy McKenzie recently has pointed to many of these same factors and concluded that bankruptcy judges increasingly act with a degree of authority and discretion more fitting of Article III judges. ${ }^{205}$ He notes, for instance, the vast

${ }^{203}$ Jill Smolowe, Estate of the Union: Bereaved but Unbowed, Model Anna Nicole Smith Wages Battle to Claim a Portion of the Millions Left by Her Ninetysomething OilTycoon Husband, PEOPLE (Nov. 15, 1999), http://www.people.com/people/archive/article/ 0,,20129774,00.html.

${ }^{204}$ Cf. BFP v. Resolution Trust Corp., 511 U.S. 531, 542-43 (1994) (noting that courts should be reluctant to infer Congressional intent to disrupt the "ancient harmony" between state debtor-creditor law and federal bankruptcy law).

205 See Troy McKenzie, Judicial Independence, Autonomy, and the Bankruptcy Courts, 62 STAN. L. REV. 747, 751-52 (2010). Professor McKenzie also argues that subsequent Supreme Court cases have essentially gutted Marathon's central holding that there is a firm constitutional line between those matters appropriate for resolution by Article I bankruptcy judges and Article III judges. See id. at 756-57 (discussing Thomas $v$. Union Carbide Agric. Prods. Co., 473 U.S. 568 (1985) and Commodity Futures Trading Comm'n v. Schor, 478 U.S. 833 (1986)). Other scholars have also argued that Marathon was implicitly overruled by Schor. See Erwin Chemerinsky, Ending the Marathon: It Is Time to Overrule Northern Pipeline, 65 AM. BANKR. L.J. 311, 320 (1991). Cases citing both Marathon and Schor, however, have not treated Schor as upsetting the core/non-core distinction, only pointing out where Schor partially limits Marathon without disturbing the central holding (i.e., waivability of core/non-core claims). See Sheridan v. Michels (In re Sheridan), 362 F.3d 96, 100 (1st Cir. 2004); Humboldt Express, Inc. v. Wise Co. (In re Apex Express Corp.), 190 F.3d 624, 631 (4th Cir. 1999) (citing Thomas v. Union Carbide Agric. Prods. Co., 473 U.S. 568 (1985), and Commodity Futures Trading Comm'n v. Schor, 478 U.S. 833 (1986)) ("Northern Pipeline remains good law, even if perhaps 
powers of bankruptcy judges, and their relative immunity to review by superior Article III courts. ${ }^{206} \mathrm{He}$ argues, however, that because bankruptcy judges are chosen by a merit-selection process rather than a political process, they may be even more insulated from political pressures than Article III judges. ${ }^{207}$ Thus, McKenzie believes that the Supreme Court should retreat from its efforts to police the boundaries of Marathon and implicitly, the core versus non-core distinction. ${ }^{208}$

We agree with McKenzie's observation that bankruptcy courts today exercise a scope of authority in practice that exceeds that contemplated by Marathon. But we disagree with his sanguinity toward this development. We instead support a greater degree of self-restraint by bankruptcy judges in the exercise of their powers, as well as tighter oversight by Article III judges. For instance, McKenzie argues that bankruptcy judges are subject to an appointment process that may be less political in nature than that for Article III judges. ${ }^{209}$ This is not obviousresearch indicates, for instance, that so-called "merit selection" of state judges does not remove political pressures on appointments, but simply redistributes these pressures to other venues (such as bar politics). ${ }^{210}$

Even if bankruptcy judges are more insulated from politics in the appointment process, this does not address the concern about the political issues involved in reappointment of bankruptcy judges or the potential for bankruptcy judges to leave the bench at the end of their term and enter private practice. McKenzie acknowledges that these pressures might lead to the capture of bankruptcy judges by the bankruptcy bar. ${ }^{211}$ Scholars who have studied other specialized courts, such as the Federal Circuit, have found a tendency for those courts to succumb to capture by repeat-players that appear before them. ${ }^{212}$ Once an Article III judge is appointed - even if the initial process is highly politicized-the judge is immune from future political pressure. Bankruptcy judges, by contrast, know that they will be held accountable one way or the other at the end of their term, and this acknowledgment casts a shadow over their behavior.

narrowed by subsequent decisions"); In re Clay, 35 F.3d 190, 193 (5th Cir. 1994). For purposes of our analysis we follow these courts in treating Marathon as being good law, while acknowledging the debate about its continued validity and scope.

${ }^{206}$ McKenzie, supra note 205, at 772.

${ }^{207} \mathrm{Id}$. at $793-94$.

${ }^{208}$ See id. at 766 (indicating that the Supreme Court has retreated from those efforts).

${ }^{209}$ Id. at 793-94.

${ }^{210}$ See Todd J. Zywicki, Public Choice and Tort Reform 17-18 (George Mason Univ. Sch. of Law: Law \& Econ Working Paper, Paper No. 00-36, 2000) (discussing state judicial "merit selection" programs).

${ }^{211}$ See McKenzie, supra note 205, at 798-805.

212 See Stuart Minor Benjamin \& Arti K. Rai, Fixing Innovation Policy: A Structural Perspective, 77 GeO. WASH. L. REV. 1, 17-18 (2008); Arti K. Rai, Engaging Facts and Policy: A Multi-Institutional Approach to Patent System Reform, 103 ColUM. L. REV. 1035, 1110 (2003); John R. Thomas, Formalism at the Federal Circuit, 52 AM. U. L. REV. 771, 792-94 (2003) (discussing how the Federal Circuit's "jurisprudence increasingly reflects a trend towards adjudicative rule formalism," which is explained in part as a response to the "lawyers [who] draft the exclusionary rules that are patent claims"). 


\section{Marshall v. Stern (Marshall v. Marshall II)}

In March 2010 the Ninth Circuit handed down its decision in Marshall v. Stern, ${ }^{213}$ which finally resolved the issue at the heart of the long litigation involving Smith's claim against Marshall's estate: whether Smith's counterclaim against E. Pierce Marshall was in fact a core issue in her bankruptcy. The Ninth Circuit held that it was not a core matter, and the ruling of Texas Probate Court was thus entitled to preclusive effect. ${ }^{214}$

As a legal matter, the Ninth Circuit held that a counterclaim is a core matter "arising in a case under" the Bankruptcy Code "only if the counterclaim is so closely related to the proof of claim that the resolution of the counterclaim is necessary to resolve the allowance or disallowance of the claim itself." ${ }^{215}$ The court held that resolution of Smith's counterclaim for tortious interference with a gift was "not a necessary predicate to the bankruptcy court's decision to allow or disallow E. Pierce Marshall's defamation claim."216

The Ninth Circuit's opinion thus closed the door on Smith's forum-shopping effort in the Marshall case. But even though the court reached the correct result, it appears to have left the door open to potential forum shopping in future cases. The underlying logic of the Ninth Circuit rests on mere timing-had the bankruptcy and district courts acted with greater haste, it would have been possible that the district court could have entered a binding judgment prior to a final judgment in the Texas court, which after all, was moving more slowly because of its state constitutional obligation to conduct a jury trial.

To allow the resolution of the forum-shopping problem to turn on nothing more than haste does not provide an adequate response to forum-shopping concerns. In fact, Judge Kleinfeld's concurrence to the Ninth Circuit's opinion appears to more fully appreciate the residual problems of the majority's opinion. ${ }^{217}$ Judge Kleinfeld notes that not only was Smith's counterclaim not a core matter, but it had almost nothing at all to do with her bankruptcy case in the first place. ${ }^{218}$ He points to several factors in coming to this conclusion: E. Pierce Marshall sought no damages, just a ruling of nondischargeability, so his claim didn't affect the size of the estate; Smith's counterclaim for money had no effect on whether his claim was dischargeable; and her counterclaim was not even really related in any meaningful way to her chapter 11 case, which was already completed with her discharge and for which all of the money was for her not her creditors. ${ }^{219}$ More fundamentally, Smith's effort to drum up a counterclaim in bankruptcy court

${ }^{213}$ In re Marshall, 600 F.3d 1037 (9th Cir. 2010).

${ }^{214} \mathrm{Id}$. at 1064.

${ }^{215}$ Id. at 1058-59. This test was adopted from an amicus brief filed on behalf of several professors, including the authors.

${ }^{216}$ Id. at 1059.

${ }^{217} \mathrm{Id}$. at 1065 (Kleinfeld, J., concurring).

${ }^{218} \mathrm{Id}$.

${ }^{219} \mathrm{Id}$. 
amounted to little more than "evasion of Pierce's constitutional right to jury trial in Texas." ${ }^{, 20}$ As Judge Kleinfeld concludes, "That evasion cannot stand shielded by bankruptcy court jurisdiction, especially when her bankruptcy was over and her debts discharged."221

Judge Kleinfeld's opinion goes still further to highlight the heart of the forumshopping issue implicated by the case, and especially the questions about the comparative advantages of the two forums for resolving different types of claims. He writes:

[Smith]'s counterclaim cannot be core because Pierce carefully framed his complaint to seek only a declaratory judgment of nondischargeability, not a judgment that his defamation claim was meritorious and not a claim for money damages caused by the defamation. Bankruptcy court is the right place to litigate whether a debt was dischargeable. Pierce could not very well obtain judgment in a Texas trial court controlling dischargeability of a debt in a California bankruptcy. Bankruptcy court is the wrong place to litigate a common law claim for personal injury to final judgment, and Pierce did not seek to litigate his personal injury claim there. ${ }^{222}$

This passage, together with the observation that relitigating the tortious interference claim in bankruptcy court essentially vitiated E. Pierce Marshall's right to a jury trial, affirms Judge Kleinfeld's recognition that although the ruling in the case was correct, it was nonetheless overly narrow in light of the larger questions at stake. By resolving the core/non-core issue narrowly on the basis of timing, the majority's opinion does not affirm the more fundamental structural bulwarks of the constitutional system. Had the court adopted an approach more like Judge Kleinfeld's, it might have marked out a brighter line going forward.

\section{CONCLUSION: A MODEST APPROACH TO BANKRUPTCY JURISDICTION}

The federal courts today are now confronted with a new form of forum shopping in bankruptcy. Litigants concerned with the likelihood of success in state or federal non-bankruptcy courts can race to the courthouse, file a bankruptcy petition, and take their chances in a more streamlined, less thorough, and often resource-constrained bankruptcy process, administered by Article I bankruptcy judges. The statutory grant of bankruptcy court jurisdiction can be construed broadly, and as Marshall's facts suggest, can be easily manipulated. Once jurisdiction is established, the primary restraint on strategic forum shopping is the self-restraint of the bankruptcy judge. Where the bankruptcy judge fails to exercise proper restraint, however, it is the duty of Article III judges to intervene to enforce
${ }^{220} \mathrm{Id}$.
${ }^{221} \mathrm{Id}$.
${ }^{222}$ Id. at $1065-66$. 
those limitations. The Supreme Court has long ago determined that the powers of a bankruptcy court are not coextensive with those of Article III federal courts, or state courts with plenary jurisdiction over private rights conferred by state law. Congress acknowledged these constitutional limitations on bankruptcy jurisdiction by enacting the 1984 amendments to the Bankruptcy Code. As the framers implicitly understood, there are sound reasons for vesting the federal judicial power in the hands of Article III judges. And as the Supreme Court implicitly understood in Marathon, it is precisely for these reasons that Article III judges serve as "backstops" to the rulings of Article I judges on matters involving private rights, treating such rulings as non-core matters to be treated as something less than the final judgment of a case.

Nevertheless, a new form of pernicious forum shopping has evolved, drawing life from the unsettled nature of the statute conferring bankruptcy jurisdiction, namely, 28 U.S.C. $\$ 157$. This statute gives bankruptcy judges and courts final order jurisdiction over matters arising from the "public rights" established by Congress pursuant to its authority under the Bankruptcy Clause of Article I, Section 8 of the Constitution. Unfortunately, the statute is vaguely worded, and some courts have interpreted it expansively, giving bankruptcy courts final order jurisdiction indistinguishable from that enjoyed by Article III federal judges.

The plain language of 28 U.S.C. $\$ 157(b)(1)$, however, when construed in light of standard but important canons of statutory construction, reveals that bankruptcy court jurisdiction is circumscribed by constitutional limitations. This plain language reading, consistent with constitutional constraints upon bankruptcy jurisdiction, permits a bankruptcy court to issue final orders only in those "core" matters "arising in" a title 11 case, or "arising under" title 11.

An interpretation of 28 U.S.C. $\$ 157(b)(1)$ which confers expansive jurisdictional powers on bankruptcy courts by granting final order jurisdiction on all "core" matters or proceedings, is an interpretation that renders the "arising in" and "arising under" language of $\$ 157$ (b)(2) superfluous. It also confers such broad jurisdiction upon bankruptcy courts as was already found unconstitutional in Marathon. Perhaps even more alarming than rendering statutory language meaningless, or conferring unconstitutional jurisdiction, such an interpretation creates the new forum-shopping problem in bankruptcy.

As the long, tortuous history of Anna Nicole Smith's bankruptcy case indicates, there is a strong incentive to engage in forum shopping-especially when hundreds of millions of dollars are at stake. In order to enable bankruptcy judges to resolve all of the issues that may arise in a bankruptcy case, they are granted a broad jurisdiction that can be cabined only loosely by statutory limits. The effective maintenance of our hybrid debt collection system rests on the faith that bankruptcy judges will exercise restraint and comity toward other systemic values. The bankruptcy saga of Anna Nicole Smith, while perhaps less entertaining than the saga of her extralegal life, is no less important. Absent rigorous policing of the state-federal boundary so as to prevent strategic forum 
shopping, Smith's case is likely to be the start of a new trend. If bankruptcy judges will not exercise self-restraint, Article III judges must exercise oversight and provide clear limits on the opportunity for strategic forum shopping. The Constitution, and sound bankruptcy policy, requires it. 